\title{
ANTIBODIES AGAINST FILAMENTOUS COMPONENTS IN DISCRETE CELL TYPES OF THE MOUSE RETINA ${ }^{1}$
}

\author{
URSULA C. DRÄGER, ${ }^{2}$ D. LOUISE EDWARDS, ${ }^{3}$ AND COLIN J. BARNSTABLE ${ }^{4}$ \\ Department of Neurobiology, Harvard Medical School, Boston, Massachusetts 02115 \\ Received August 4, 1983; Revised February 10, 1984; Accepted February 10, 1984
}

\begin{abstract}
Three monoclonal antibodies have been raised against the ganglion cell layer of the adult mouse retina. The first antibody, R3, labeled optic axons in the inner retina, and with colchicine pretreatment somata and dendrites of large ganglion cells could be seen. A small number of other processes, including fibers projecting to the retina from elsewhere (efferent fibers), were also labeled in the inner retina. In the outer plexiform layer R3 stained the axonless class of horizontal cells. R3 recognized a 185,000- to 200,000-dalton polypeptide which is most probably the heaviest of the neurofilament subunits. Antibodies R4 and R5 labeled filamentous components mainly in glia and cells of mesenchymal origin. The antigens appeared in most but not quite all locations morphologically closely related to the intermediate filament protein vimentin. In the retina both antibodies labeled strongly the regularly spaced Müller glia. The astroglia of the optic fiber layer was stained with R5 but not R4. Although the two antigens were in general not expressed in neurons, they were both present in axonless horizontal cells in the outer plexiform layer, coexisting with neurofilaments in this neuron.
\end{abstract}

The ganglion cell layer of the retina contains functionally different types of cells: several classes of ganglion cells, amacrine cells, and glia. With conventional histological methods these cell types are not easily distinguished, especially in retinas of species such as the mouse with small eyes, where cells tend to be somewhat smaller and are not grouped into distinct size classes (Dräger and Olsen, 1980, 1981). Hoping to find immunological means that would facilitate distinction between cell types, we have raised monoclonal antibodies against the isolated ganglion cell layer of the adult mouse. Three of the antibodies that we found to label particular cell types will be described here. All of them labeled fibrillar components within cells in a pattern reminiscent of one type of cytoskeletal element, the intermediate filaments.

Five biochemically different classes of intermediate filaments can be distinguished, four of which have been localized with immunohistochemical methods to cell types in the brain. Neurofilaments are found exclusively in neurons, the glial

\footnotetext{
${ }^{1}$ We thank Drs. K. Akagawa, B. Beltz, S. Burden, R. Hofstein, T. Jessell, W. Matthew, and E. Raviola for helpful discussions; Drs. D. Dahl and A. Bignami for the gift of GFAP antiserum; Dr. R. Hynes for vimentin antisera; Dr. J. Wood for the neurofilament antibody RT 97; Dr. K. Fujiwara for 3T3 cells; Dr. E. A. Schwartz for $\epsilon^{t}$ c. 1 cells; Scott Cinsavich and Elizabeth Silvestro for technical assistance; and Olivia Brum for putting the manuscript together. The work was supported by National Institutes of Health Grants EY 01938, EY 03735, EY 07042, and NS 17309

${ }^{2}$ To whom correspondence should be addressed.

${ }^{3}$ Present address: Massachusetts General Hospital, Boston, MA 02114.

${ }^{4}$ Present address: Department of Neurobiology, Rockefeller University, New York, NY 10021.
}

fibrillary acidic protein (GFAP) is found only in some forms of macroglia, and vimentin and desmin are seen in some glial types and in cells of mesenchymal origin (Bromberg and Schachner, 1978; Franke et al., 1978; Liem et al., 1978; Schachner et al., 1978; Bignami and Dahl, 1979; Lazarides, 1980, 1981; Dahl et al., 1981a, b; Dixon and Eng, 1981; Schnitzer et al., 1981; Yen and Fields, 1981; Dahl and Bignami, 1982; Beale and Osborne, 1982). Neurofilaments are composed of three subunits, the 68,000-, 150,000-, and 200,000-dalton proteins forming a triplet, which are thought to occur closely associated in adult neurons but have been reported to be under separate control during development (Hoffman and Lasek, 1975; Willard and Simon, 1981; Sharp et al., 1982; Shaw and Weber, 1982, 1983). Long before antibodies to intermediate filaments became available, anatomists had used heavy metal stains with affinity for fibrillar components in particular cell types, such as reduced silver methods for neurofibrils. Neurofibrillar stains have been shown to label neurofilaments (Gray and Guillery, 1961; Guillery, 1970; Potter, 1971; Gambetti et al., 1981). Anatomical studies of the retina based on neurofibrillar staining methods provide the background for comparison with our first antibody, R3, that appears to be directed against neurofilaments (Embden, 1901; Sala, 1904; Ramon y Cajal, 1911; Cattaneo, 1922; Gallego, 1964, 1982; Honrubia and Elliott, 1968, 1969, 1970; Wässle et al., 1978, 1981; Vaney et al., 1981). Although R3 seemed to label most structures known to stain with neurofibrillar methods, it was more selective in the inner retina.

For the other two monoclonal antibodies, R4 and R5, we do not know the antigens recognized. Both of them labeled fibrillar components mostly in non-neuronal cell types in a pattern similar to the distribution of the intermediate filament protein vimentin. However, comparisons with vimentin antisera showed that the two antibodies labeled most but not all vimentin-positive structures. 


\section{Materials and Methods}

Antibody production. Isolated ganglion cell layers of adult C57BL/ $6 \mathrm{~J}$ mice (all mice from Jackson Laboratory, Bar Harbor, ME) were used as antigen. Mice were anesthetized with Nembutal and perfused through the heart with $4 \%$ paraformaldehyde; the retinas were flattened onto a leveled block, and the ganglion cell layers were shaved off on a cryostat. One to $2 \mathrm{mg}$ of tissue (dry weight), from 5 to 10 mice, were injected repeatedly into $\mathrm{Balb} / \mathrm{c}$ mice. We followed the immunization schedule, procedures of fusion, and cloning used by Barnstable (1980, 1982). As plasmacytoma the nonsecreting line P3x63 Ag8.653 was chosen. The supernatants of growing hybrid colonies were screened by indirect immunofluorescence on cryostat sections of formalin-fixed retinas from adult $\mathrm{C} 57 \mathrm{BL} / 6 \mathrm{~J}$ mice. The three hybridomas described here were each cloned three times by limiting dilution. Spent tissue culture supernatants were used for all tests at appropriate dilutions. Antibody subclasses were determined with fluorochrome-conjugated subclass-specific antibodies (Nordic; kindly supplied by Dr. S. Burden) on cryostat sections. All three antibodies were of the IgM class. The hybridoma cell line of Pruss et al. (1981) was purchased from American Type Culture Collection.

Histology. Formalin-fixed retinas were either processed as whole mounts or sectioned transversely or tangentially (horizontally) on a cryostat. As well as normal retinas of $\mathrm{C} 57 \mathrm{BL} / 6 \mathrm{~J}$ mice, we used retinas from mice with photoreceptor degeneration $(\mathrm{C} 3 \mathrm{H} / \mathrm{HeJ} r d / r d$; Sidman and Green, 1965), since antibody penetration in whole mounts was better in these thinner retinas (Figs. 7 and 16). Degenerate retinas were similar to normal with respect to the labeling in the inner retina. But because there was a difference in the outer retina (Dräger and Edwards, 1983), we limit the description of the outer plexiform layer here to the normal mouse. Specimens were processed for indirect immunofluorescence, using secondary antibodies labeled with fluorescein isothiocyanate (FITC) or rhodamine isothiocyanate (RITC; Boehringer Mannheim; Cappel). Addition of 0.3 to $1 \%$ Triton X-100 improved the staining of sections and was essential for whole mount preparations. For double labeling with a rabbit antiserum to glial fibrillary acidic protein (GFAP; a gift from Drs. D. Dahl and A. Bignami), an FITC-labeled anti-mouse antibody was combined with an RITC-labeled anti-rabbit antibody (see Fig. 17) or vice versa. In all preparations appropriate controls were run to test for nonspecific binding of primary and secondary antibodies and, for double label experiments, to ensure that the secondary antibodies reacted only with the immunoglobulin species against which they were raised.

In some mice the eyes were injected with 5 to $10 \mu \mathrm{g}$ of colchicine (Sigma) 3 to $45 \mathrm{hr}$ (optimal $21 \mathrm{hr}$ ) prior to perfusion. Taking into account the small volume of the vitreous chamber in the mouse eye, this amounted to a transient colchicine concentration of about $10 \mathrm{mg} /$ $\mathrm{ml}$ but probably a relatively fast decline. In a few mice one optic tract was injected with horseradish peroxidase (HRP) 2 days prior to colchicine application (Dräger and Olsen, 1980). The retinas were reacted for HRP following the protocol of Hanker et al. (1977) and were processed for indirect immunofluorescence.

Brains were taken from paraformaldehyde-perfused mice, sectioned on a cryostat, and processed for indirect immunofluorescence. Cultured cells used for characterization of antibodies R4 and R5 were either fibroblasts extracted from newborn rat lungs (Fig. 13, $A$ and $B$ ), cells of the 3T3 fibroblast line (Fig. 13, $C$ to $F$; a gift from Dr. K. Fujiwara), or cells of the $\epsilon^{t}$ c. 1 line (Fig. 13, $G$ and $H$; Bulloch et al., 1978) cells were a gift from Dr. E. A. Schwartz). Cells were either grown on coverslips or on subbed slides with RPMI 1640 medium plus $10 \%$ fetal calf serum, before they were fixed with $4 \%$ paraformaldehyde and processed for indirect immunofluorescence. In some of the cultures 20 $\mu \mathrm{g} / \mathrm{ml}$ of colchicine were added to the medium $15 \mathrm{hr}$ before fixation (Hynes and Destree, 1978).

All preparations were viewed with a Leitz Dialux fluorescence microscope equipped with Zeiss and Leitz lenses. Fading of the fluorescent tags was prevented with $p$-phenylene diamine (Johnson and Nogueira Aranjo, 1981). When this compound was left to oxidize, it provided a convenient orange-colored nuclear counterstain that was visible only with the less selective H2-cube for FITC (Leitz), but it could be blocked out by the more selective L2-FITC-cube.

Immune blots. Adult mice were quickly perfused through the heart with $1 \mathrm{mM}$ EDTA; the brains were immediately placed into liquid nitrogen, pulverized, and lyophilized. Aliquots of brain powder were dissolved in preheated sample buffer ( $2 \%$ SDS, $5 \%$ 2-mercptoethanol, $10 \%$ glycerol, $0.01 \%$ bromphenol blue in $0.625 \mathrm{M}$ Tris- $\mathrm{HCl}, \mathrm{pH} 6.8$ ) and kept for 3 to $5 \mathrm{~min}$ at $100^{\circ} \mathrm{C} ; 75$ to $150 \mu \mathrm{g}$ of protein were loaded onto a 5 to $15 \%$ linear gradient polyacrylamide gel, and electrophoresis was performed using the buffer system of Laemmli (1970). Proteins were transferred from the gel onto nitrocellulose paper according to Towbin et al. (1979). Strips of nitrocellulose paper were either stained for protein with amido black or blocked with $5 \%$ normal goat serum and processed for antibody binding using peroxidase-labeled secondary

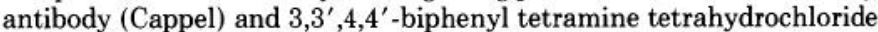
(MCB Chemicals) as chromogen.

\section{Results}

\section{Antibody R3}

Immunoblot. On blots from SDS-polyacrylamide gels, antibody R3 stained strongly a band at 185,000 to 200,000 daltons and very faintly a band at 140,000 to 150,000 daltons (see Fig. $1)$. To test whether these bands were likely to represent intermediate filaments, we compared R3 to a monoclonal antibody against a common site on all intermediate filaments (Pruss et al., 1981). On adjoining strips of blots the 185,000 - to $200,000-$ dalton band of R3 lined up precisely with a band stained by the Pruss antibody; in the 140,000 - to 150,000 -dalton region the staining was too weak to be certain. This, taken in conjunction with the histological appearance of the antigen (see below) and comparisons with other antibodies, suggested that R3 recognizes neurofilaments. The strongly stained band most

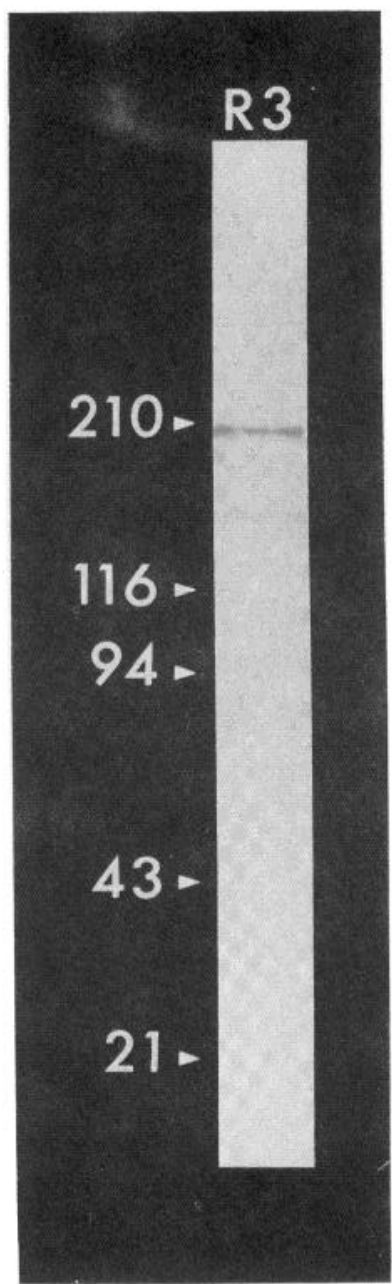

Figure 1. Immunoblot of antibody R3. Molecular weight standards at left were myosin ( 210,000 daltons), $\beta$-galactosidase ( 116,000 daltons), phosphorylase B ( 94,000 daltons), ovalbumin (43,000 daltons), and soybean trypsin inhibitor (21,000 daltons). 
likely corresponds to the heaviest subunit of the neurofilament triplet. The faintly labeled band may represent a weak crossreactivity of the antibody with the intermediate molecular weight subunit or with a breakdown product of the high molecular weight subunit.

Transverse sections through retina. In transverse sections of the retina (Fig. 2) the most prominent labeling with $\mathrm{R} 3$ was in the outer plexiform layer and in the ganglion cell layer. In the inner lamina of the outer plexiform layer (i.e., adjoining the inner nuclear layer) a dense network of thick processes was stained; this was similar in apperance throughout the extent of the retina. In contrast, the labeling in the ganglion cell layer was strongest in central retinal regions, but it thinned out and disappeared toward the retinal periphery; it consisted mainly of sections through optic fiber bundles (see below). Much less conspicuous labeling with R3 was seen in the inner plexiform layer in the form of thin, mostly horizontally oriented fiber segments. Usually no cell bodies were heavily labeled, but at higher magnifications some very low level of labeling, barely distinguishable from background, could be determined in many cells of the ganglion cell layer and in a few cells at the inner margin of the inner nuclear layer. Only very rarely did a large cell body in the ganglion cell layer stand out.

Retinal whole mounts: Inner retina. To visualize the topographical distribution of the staining, we applied the antibody to whole mount preparations. Such specimens showed that the

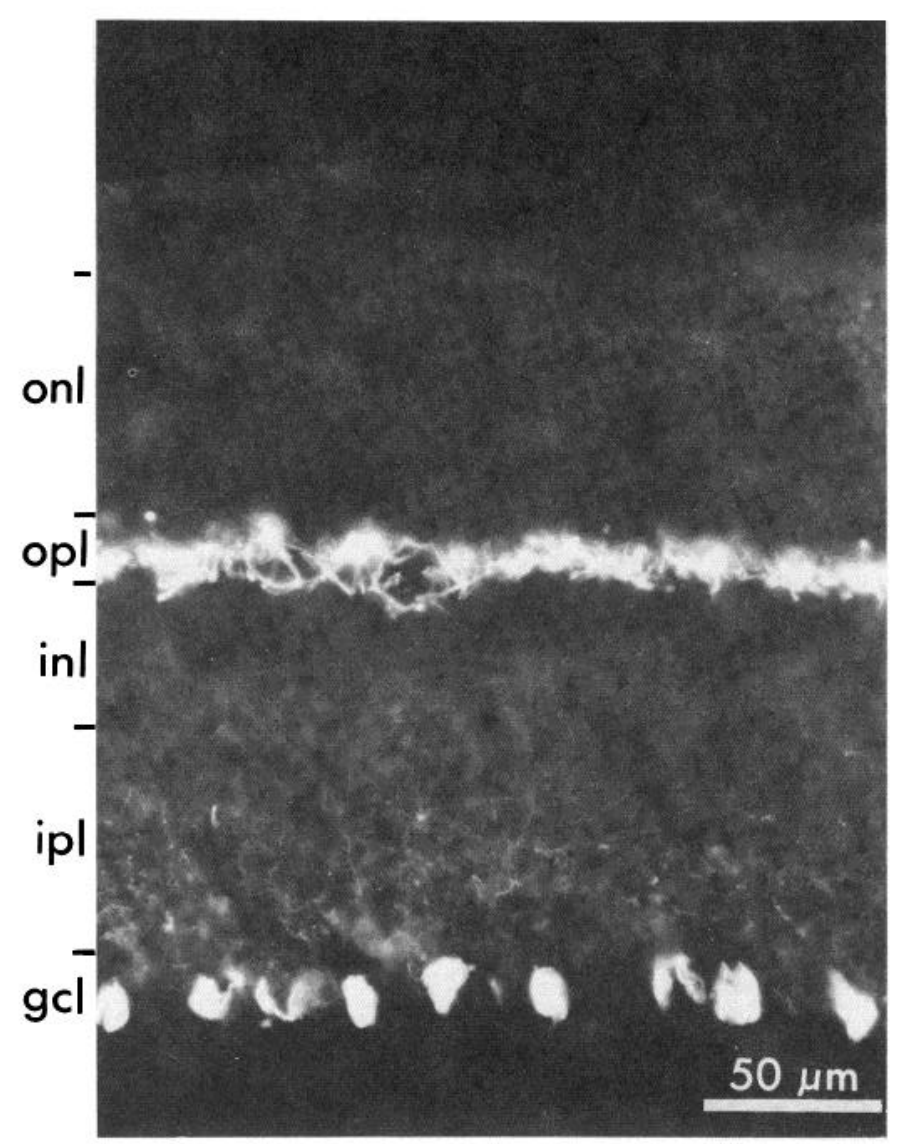

Figure 2. Transverse section through the central region of the retina, reacted with the neurofilament antibody R3. Retinal laminae are indicated: onl, outer nuclear layer; opl, outer plexiform layer; inl, inner nuclear layer; $i p l$, inner plexiform layer; $g c l$, ganglion cell layer. The bright blobs in the ganglion cell layer are sections through optic fiber bundles. No colchicine was applied to this retina, and no ganglion cell bodies are visible. fibers in the ganglion cell layer converged onto the optic disk and, hence, for the most part, must be optic axons. For the large majority of fibers, the staining was strongest close to the optic disk but gradually tapered out and disappeared toward the retinal periphery. In many retinas one or two fibers could be seen arising from a heavily labeled ganglion cell body. There was no consistent pattern to these rare completely labeled cells except that they were of large size and seemed to be more common in old mice.

In an attempt to visualize more of the cell bodies that gave rise to the labeled fiber segments, we injected the eyes of mice with colchicine. A few hours after injection, the labeling of optic axon segments had generally progressed toward the retinal periphery and the labeling was more intense. Then, gradually increasing in frequency with time after injection, the initial segments of many ganglion cell axons became visible as extended calices, and ghost-like ganglion cell bodies began to show up. After 20 to $24 \mathrm{hr}$ of colchicine exposure, many large ganglion cell bodies with dendrites were heavily labeled, but some axons had started to become disrupted, decomposing into chains of tiny rings along their course. Forty-five hours after colchicine application, most of the R3-stainable material had disappeared, and the retina seemed to undergo general necrosis. Except for the somata and dendrites of large ganglion cells, colchicine treatment did not bring out any other R3-positive structures in addition to those seen in untreated retinas.

Figure 3 is a low power view of a sector of an R3-labeled retina from an eye injected with $7 \mu \mathrm{g}$ of colchicine $22 \mathrm{hr}$ before perfusion. Many ganglion cells are visible, sending off axons toward the optic disk. The density of labeled cells was consistently higher in peripheral than central retina, which was caused by the intraocular colchicine application, probably because peripheral ganglion cells had longer portions of their axons exposed to the drug than more central ganglion cells. No such topographical preference of labeled cell bodies was obvious after intraperitoneal injection of the drug, but this mode of application was unsatisfactory due to the general toxicity of colchicine. In Figure 4, a high power view of a ganglion cell, filamentous material can be seen winding around the nucleus in the soma region and extending into the dendrites that project out of focus into the inner plexiform layer. The distribution of fibrillae in cell body and dendrites in colchicine-treated retinas was not

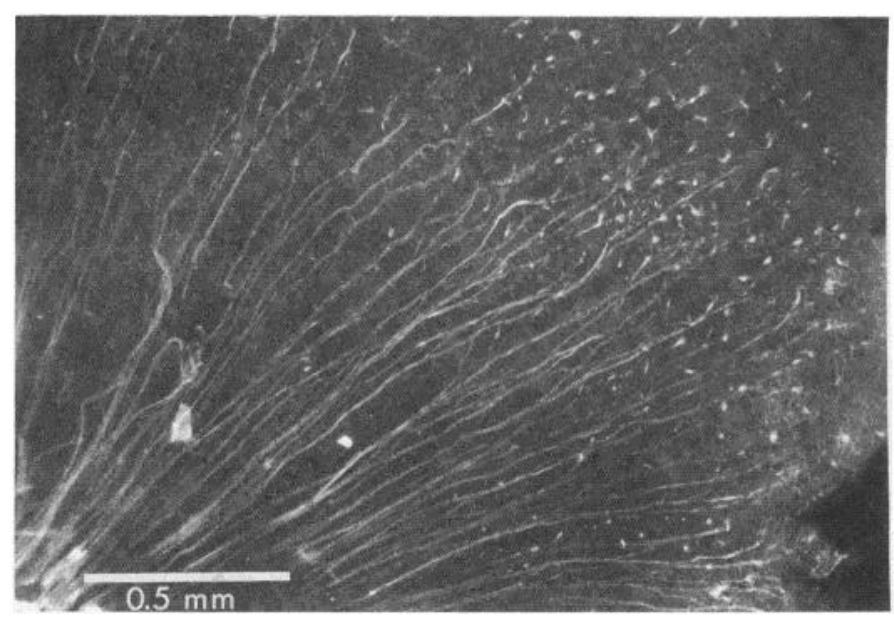

Figure 3. Low power view of a retinal whole mount from a C57BL/6J mouse. The eyes had been injected with colchicine $22 \mathrm{hr}$ prior to perfusion. To the left, just beyond the margin of the photomicrograph, is the optic disk; the right margin is close to the ciliary border of the retina. The specks located mainly in the peripheral retina are cell bodies of large ganglion cells; their axons can be seen converging onto the optic disk. 


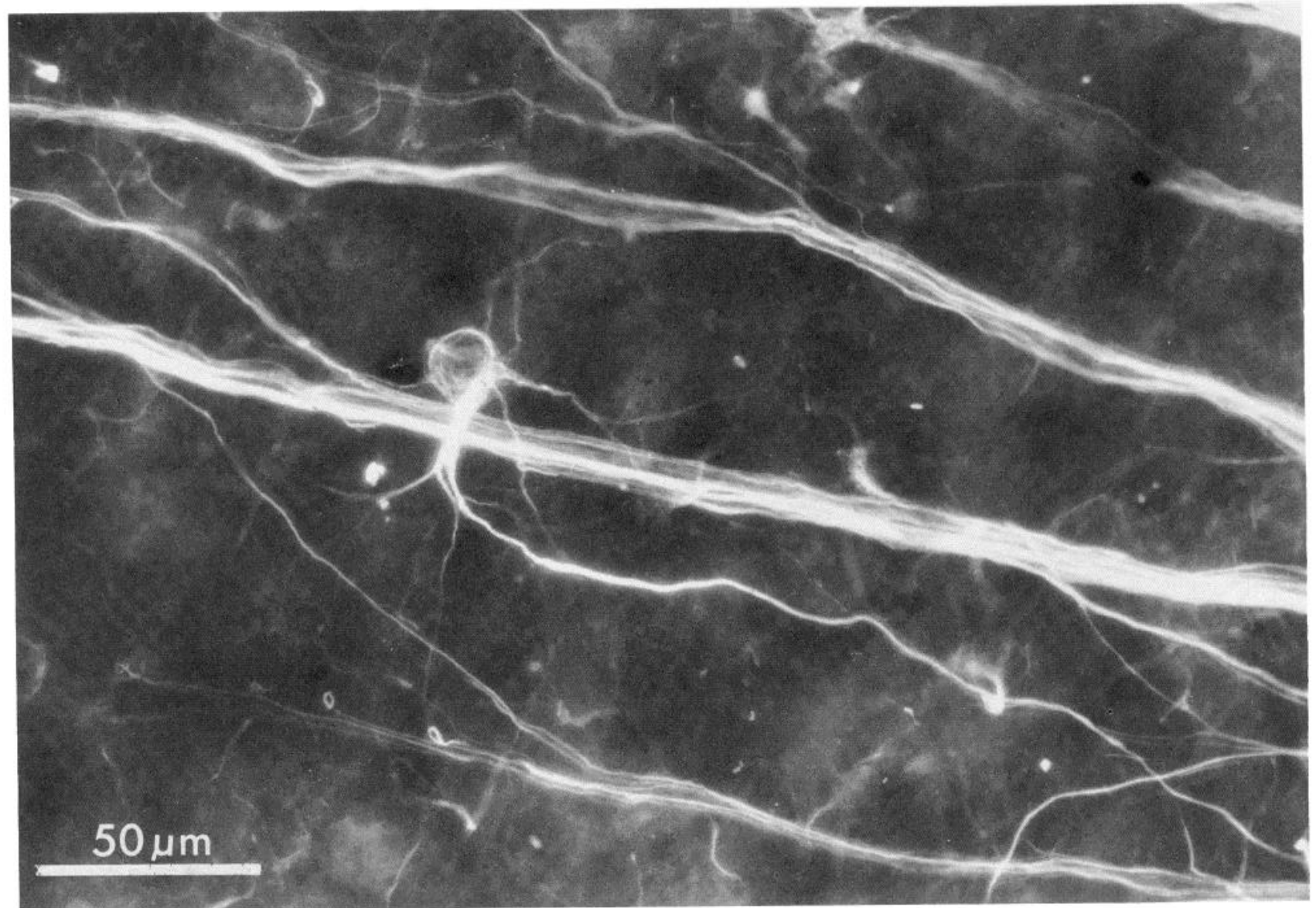

Figure 4. Large ganglion cell and optic axons from a C57BL/6J retina exposed to colchicine. The dendrites project into the inner plexiform layer, out of focus in this photomicrograph; they could be followed for about $150 \mu \mathrm{m}$ in every direction. The initial portion of the axon of this cell appears swollen, probably due to the colchicine treatment.

notably different from the pattern in the occasional ganglion cell labeled in untreated retinas. In addition to the ganglion cells in the ganglion cell layer, many axons could be followed to displaced ganglion cells in the inner nuclear layer. Although displaced ganglion cells make up less than $1 \%$ of the total ganglion cell population in the mouse (Dräger and Olsen, 1980), about $6 \%$ of the R3-labeled ganglion cells were displaced ones. The ganglion cells that were stained represented a small fraction of the entire population-in the best preparations less than 2000 cells or about 2 to $3 \%$ of the total. Since there was some variability in cell body staining related to the colchicine pretreatment, this number can only be taken as a lower limit. All labeled cells had large soma diameters, as illustrated in the cell size histograms of Figure 5 that compare R3-labeled cells with the overall ganglion cell population from corresponding retinal regions (Dräger and Olsen, 1981).

While labeled ganglion cells could be counted easily, it was impossible to count optic axons at the light microscopic level. Nevertheless, there seemed to be many more axons labeled than cell bodies. In sections through the optic nerve the large axons stood out in relative labeling intensity, but the majority of axons appeared to be labeled to some extent. Although it is possible that the labeled cell bodies represent one functional class of ganglion cells, it would thus appear unlikely that functional classes of axons can be distinguished with this neurofilament antibody.

We have not seen any centrally projecting ganglion cell axons giving off collateral branches within the retina, but there were at least two types of R3-positive axonal branches in the inner retina. The first type corresponded to the associational ganglion cell of Gallego and Cruz (1965), an example of which is shown in Figure 6. A large cell body located in the ganglion cell layer, with an obvious dendritic tree, can be seen giving off an axon that branches repeatedly and projects in a circumferential course in the inner plexiform layer. Two lines of evidence argued against a central projection. First, none of the labeled processes headed toward the optic disk. Second, 2 days prior to the intraocular colchicine application the optic tract contralateral to the retina shown had been injected with HRP, which labeled most of the ganglion cells projecting into the tract but not the cell in Figure 6 . We have seen complete labeling of this cell type only a few times, but in many retinas branching processes could be found that resembled the axonal arbor of this cell.

The second type of axonal branches in the inner retina arose from thick fibers entering the eye through the optic disk, which defines them as efferent fibers (called efferent with respect to the brain, but an origin in the opposite eye cannot be excluded). Figure 7 shows such a fiber, at low power in $A$ and at higher magnifications in $B$ to $F$. Since most of these efferent fibers were thicker than most of the optic axons, stained brighter, and tended to run superficially in the fiber layer, they could be followed without difficulty from the optic disk in their course over the retina. When these processes ran parallel with the optic axons they tended to travel in the ganglion cell layer, but when they took an oblique course they dipped down into the inner plexiform layer. They seemed to terminate high in the inner plexiform layer or at the inner edge of the inner nuclear 


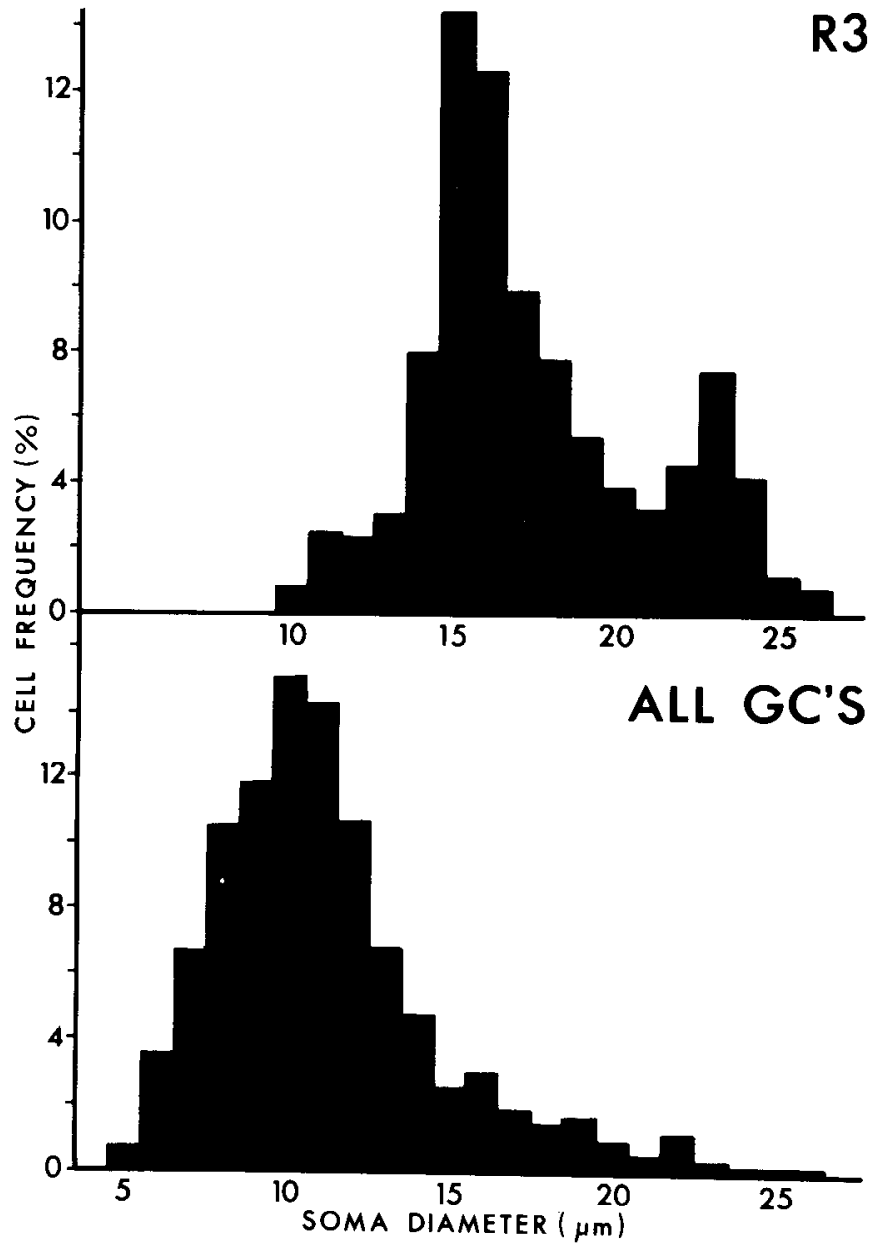

Figure 5. Cell size histogram of 97 ganglion cells labeled with R3 after colchicine exposure (upper graph), compared with the overall population of ganglion cells $(n=2344)$ in intermediate and peripheral retina, as determined fromNissl-stained whole mounts (lower graph).

layer. Figure $7 C$ shows one of the branching points at higher magnification, and Figure $7 D$ shows the terminal staining of one of the arbors. Since in most cases neurofilaments do not enter the synaptic terminal itself but taper out just before, synaptic endings usually cannot be demonstrated with neurofilament-specific methods (Guillery, 1970; Peters et al., 1976). Thus, the short branchlets here are presumably close to synaptic terminals. In addition to the type of efferent fiber that seemed to terminate in the vicinity of the main layer of amacrine cell bodies, we could also follow fibers from the optic disk to the outer plexiform layer and even to the photoreceptor outer processes. A fiber of the last type is shown in Figure 8. Most retinas contained one or a few $\mathrm{R} 3$-labeled efferents, but there was no consistent topographical pattern to their projection, and neither did they correlate with the sex of the animal or with the origin of the retina from the left or right eye. (C57BL/ 6J mice frequently have an ocular malformation, coloboma and microphthalmia, that in most cases affects only the right eye.)

Figure 9 illustrates another peculiar type of fiber, which apparently originates from the optic disk, loops around, and appears to head back toward the disk. Several of these loops were seen in most retinas. Usually they remained confined to the ganglion cell layer (see Fig. $7, E$ and $F$ ), but in a few cases the turn was around horizontal cells or in the layer of photoreceptor outer processes. While most of the looping fibers were of relatively thick caliber, they could be of any diameter, and they intermingled with the optic axons, making it impossible to follow them unambiguously into the optic disk. Although they may represent axons of ganglion cells located close to the optic disk, so far we have never been able to trace any of them back to a cell body.

A system of fine fibers, much thinner in diameter than the efferent fibers, could be distinguished with $\mathrm{R} 3$ in the inner plexiform layer (Fig. $7 F$ ). 'These fibers tended to run in a relatively straight horizontal course without tapering in diameter and often extending for many hundreds of micrometers, giving off only a few branches (see Fig. 10A). Their appearance was not consistent with the dendritic morphology of ganglion cells, but rather resembled the processes of the wide field amacrine cells described in Golgi-stained material of the rodent retina (Perry and Walker, 1980; Perry, 1981). So far we have not been able to identify their cell bodies.

In the inner stratum of the inner nuclear layer a population of cells was very faintly labeled. These cells had small somata and were spaced quite regularly at about $45 \mu \mathrm{m}$ between nearest neighbors, which distinguished them from displaced ganglion cells that are larger and irregularly spaced (Dräger and Olsen, 1980) (see Fig. 10B). They did not seem to be the source of the fine fibers in the inner plexiform layer mentioned above. Most likely they corresponded to one of the two populations of amacrine cells stained with neurofibrillar methods in the rabbit retina (Vaney et al., 1981). It may be that in the mouse, as in the rabbit, a matching population of neurofilamentous amacrine cells is displaced to the ganglion cell layer, but because of the faint labeling of these cells in the mouse and the relatively high background in the ganglion cell layer, we could not make out such a population with confidence.

Outer plexiform layer. Figure 11 shows an R3-stained whole mount with focus on the outer plexiform layer. A dense network of thick processes can be seen which branches a few times before tapering off into slender endings. Camera lucida tracings of single elements from this tangle were difficult since the fine endings were often in close apposition to each other. One example of a traced cell is shown in Figure 12 . The cell body was not labeled, and its location could not be deduced from the branching pattern of the processes. This cell was more or less characteristic of several camera lucida drawings we made, but since we may have selected for cells that were easier to trace, it is not necessarily representative for the entire population. It resembled one of the two types of horizontal cells present in most mammalian species, the axonless horizontal cell, a neuron known to be exceptionally rich in neurofilaments (Fisher and Boycott, 1974; Kolb, 1977; Boycott et al., 1978; Bloomfield and Miller, 1982; Dacheux and Raviola, 1982; Gallego, 1982).

\section{Antibodies $R 4$ and $R 5$}

General characteristics. The antibodies R4 and R5, like R3, labeled fibrillar components within cells, but except for one unusual neuron the antigens recognized were restricted to cells of mesenchymal origin and to types of macroglia. Because the antibodies reacted only poorly with the denatured material on immunoblots, we tried to characterize the antigens immunohistochemically with respect to vimentin, to which they appeared morphologically related. For this comparison we used cells grown in culture rather than retina sections, in order to avoid problems of tissue penetration and to allow for a flatter field of view. In fibroblasts both $\mathrm{R} 4$ and $\mathrm{R} 5$, like vimentin antisera, labeled a system of intracellular fibrillae. After several hours of exposure to colchicine, the R4- and R5-labeled fibrillae, like the vimentin filaments, collapsed into a perinuclear coil (Hynes and Destree, 1978) (see Fig. 13, $A$ and $B$ ). On examination at high power the labeling of fibroblasts with the two monoclonal antibodies differed to some extent. The R5 antigen followed the vimentin-positive filaments in every detail discernible at 

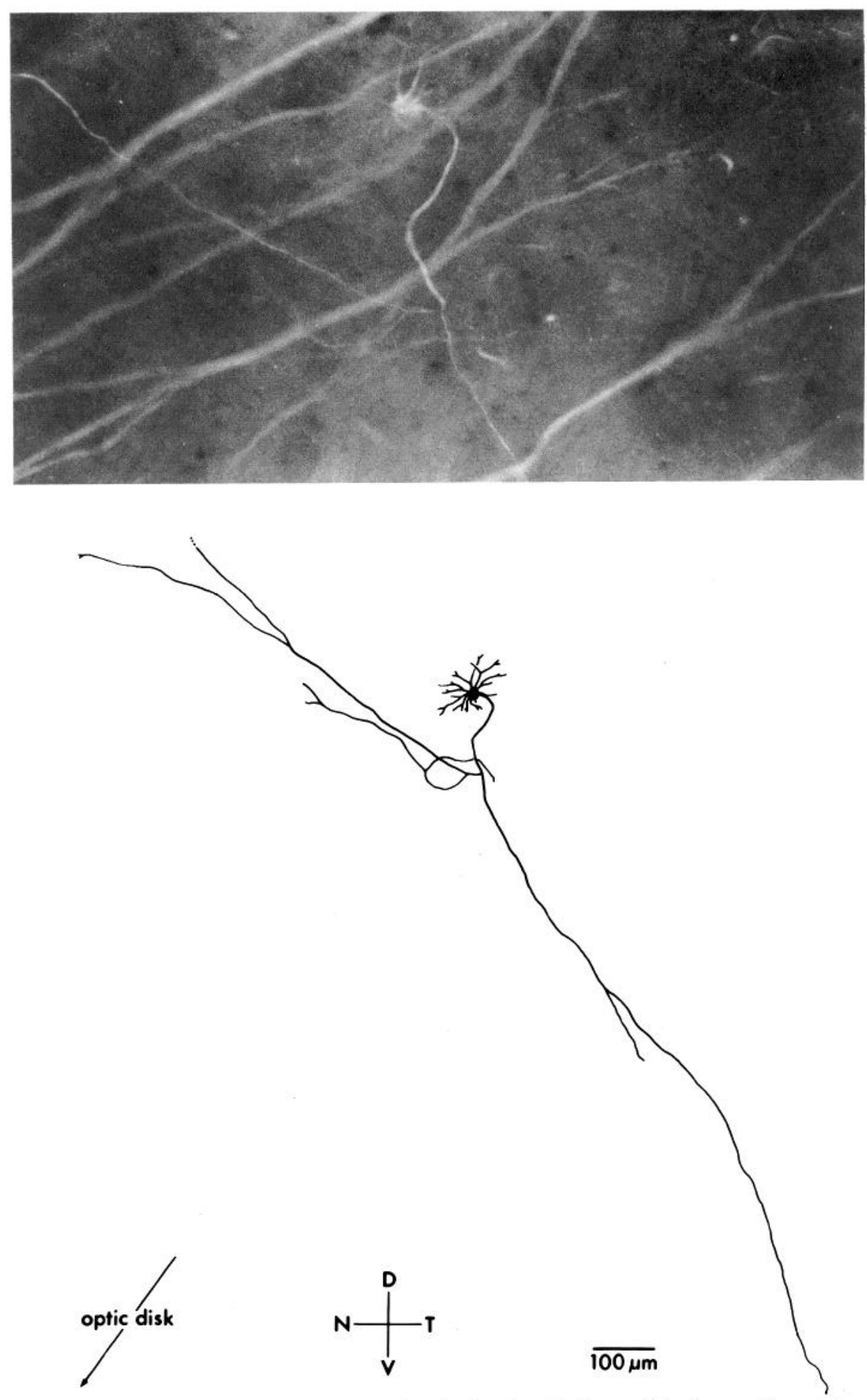

Figure 6. Photomicrograph and camera lucida drawing of a large cell in the ganglion cell layer with dendrites and axon that arborize in the inner plexiform layer. The cell was located in the upper nasal retina. Some of the ganglion cells filled with HRP from the contralateral optic tract are visible as dark specks in the low power photomicrograph.

the light microscopic level (see Fig. 13, $C$ and $D$ ). In contrast, the R4 antigen was distributed inhomogeneously along the vimentin-positive fibrillae. It paralleled them precisely in some places but appeared fragmented along the thinner vimentin fibrillae or was missing completely (see Fig. $13, E$ and $F$ ). In addition, the $\mathrm{R} 4$ antigen was to some extent affected by excessive treatment with detergent: exposure to $1 \%$ Triton over 24 $\mathrm{hr}$ at room temperature caused a relative dispersion of the R4 antigen, whereas vimentin and the R5 antigen were unaffected. These observations, as well as the distribution of the R4 antigen in the retina, indicated that the R4 antigen was probably not vimentin. By contrast, the R5 antigen seemed to parallel vimentin faithfully both in the retina as in fibroblasts, but there was one exception: In $\epsilon^{\prime} c .1$ cells, a cell line of uncertain identity 

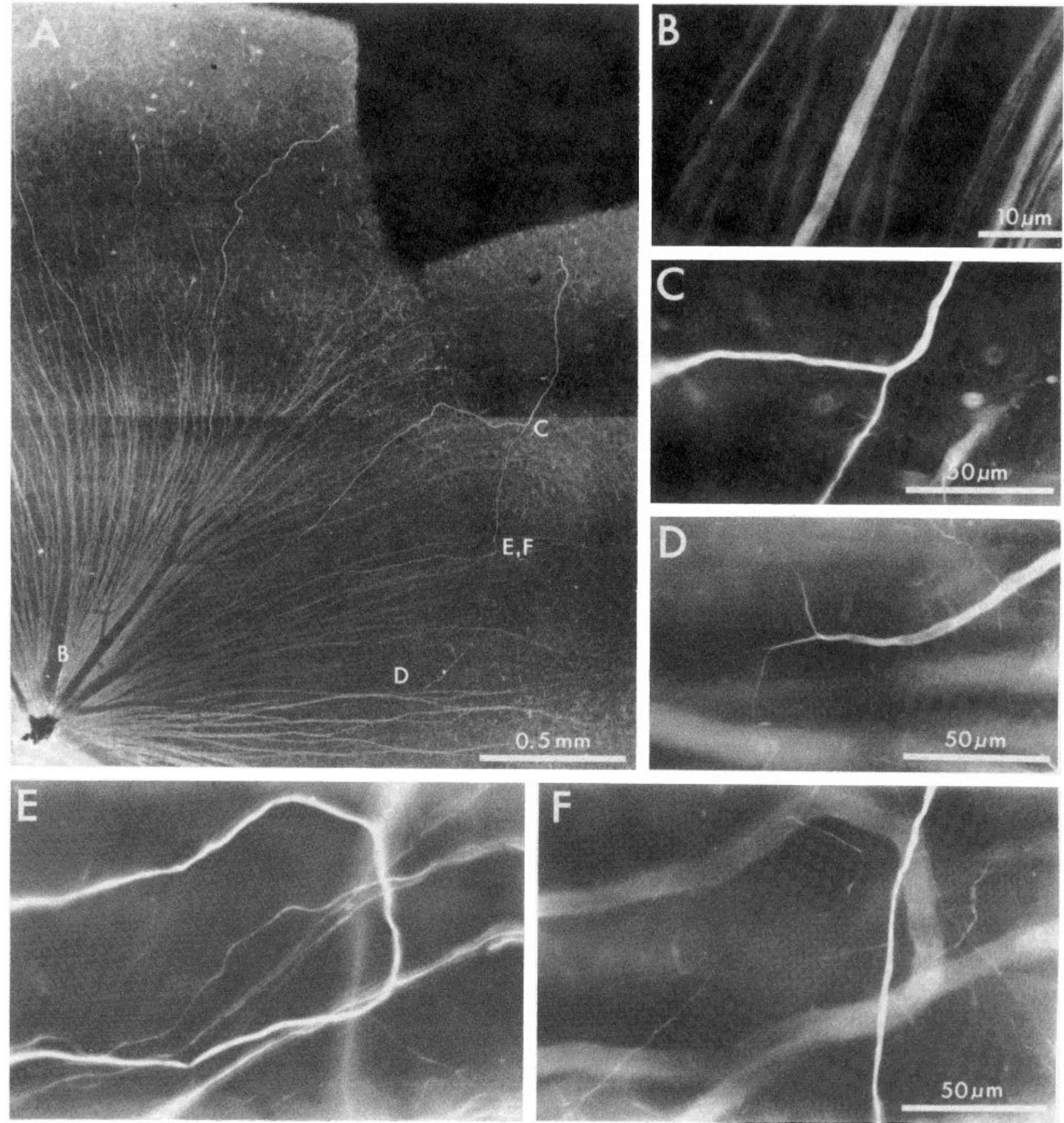

Figure 7. Efferent fiber in a $\mathrm{C} 3 \mathrm{H} / \mathrm{HeJ} r d / r d$ retina; the eye had been injected with $10 \mu \mathrm{g}$ of colchicine $9 \mathrm{hr}$ prior to perfusion to increase staining intensity; hardly any ganglion cell bodies are visible. $A$, Low power view; the efferent fiber, sectioned at the releasing cut of the whole mount, stands out due to its thick caliber and intense labeling. The locations of the high power views in $B$ to $F$ are indicated. $B$, Efferent fiber close to optic disk; here the fiber measured almost $3 \mu \mathrm{m}$ in diameter, but it decreased in diameter on its course through the retina. $C$, Branching point; as a rule, the acute angle of the branch was distal to the optic disk, indicating an extraretinal location of the cell body of origin. $D$, Terminal labeling of one of the branches. $E$ and $F$, Same field, but focus in $E$ on a looping fiber in the ganglion cell layer and in $F$ at the level of the efferent fiber running in the inner plexiform layer.

but originally selected for neuronal characteristics from cultures of mouse cerebellum (Bulloch et al., 1978), the R5 antigen appeared as granular material along the vimentin fibrillae, often with highest concentrations in perinuclear regions of the cells (see Fig. 13, $G$ and $H$ ).

Müller glia. In cross-sections through the retina, the staining patterns of the two antibodies were very similar. The most prominent labeling was of the radial fibers in the main type of retinal glia, the Müller cells. These fibers enveloped the cell somata of the ganglion cell layer and extended outward toward the outer limiting membrane (Fig. 14). Between the cells of the outer nuclear layer the radial fibers were more weakly labeled than in the inner retina. Staining in outer layers was relatively strongest in peripheral retina but tended to be sparse or not visible at all in central retinal regions. The cell bodies of the Müller cells showed up most often as kinks in the course of the radial fibers (see the arrow in Fig. 14) or more rarely as fusiform or diamond-shaped outlines external to the amacrine cells in 

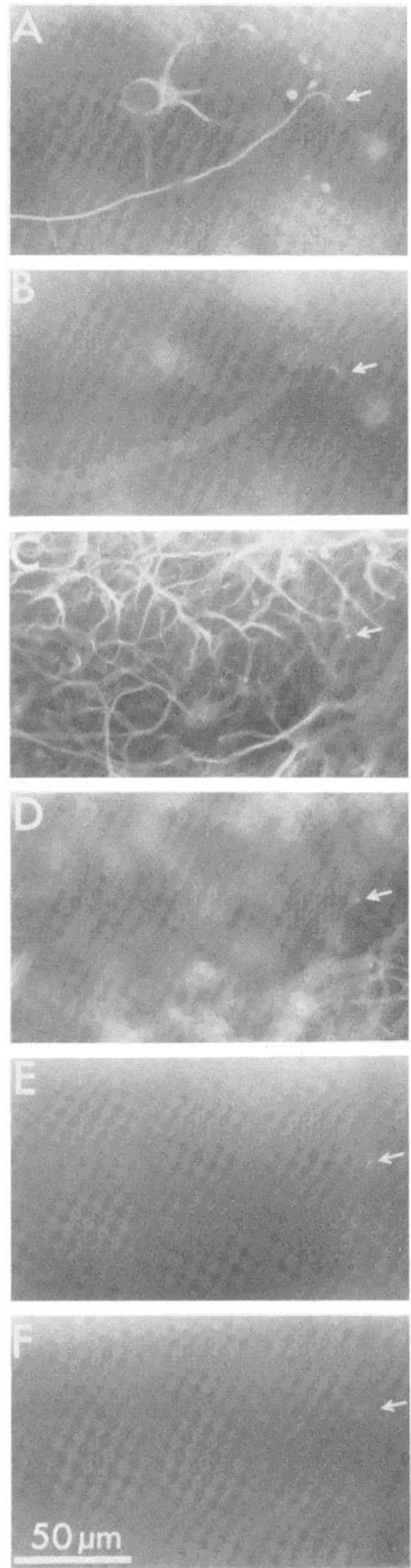

Figure 8. Photomicrographs of an R3-positive fiber coming from the optic disk and turning toward the outer retina. Frames are taken at focal planes progressing outward from the ganglion cell layer $(A)$ to the level of the photoreceptor inner segments $(F)$. Frames shown are the inner nuclear layer. At higher magnifications and most noticeable in peripheral retina, the outer limiting membrane was labeled, which is the zone of tight junctions between Müller cells and the basal portions of the photoreceptor outer processes. In flat view the radial glia fibers were spaced in a nearly regular mosaic with a mean distance of 7 to $8 \mu \mathrm{m}$ between neighboring fibers and a density of about 12,000 fibers $/ \mathrm{mm}^{2}$. Figure 15 shows a horizontal section through the upper lamina of the inner plexiform layer, labeled both with R4 and R5.

When the retina had been exposed to colchicine, the labeling was overall brighter and the fibrillae in the Müller cells appeared somewhat coarser, but their distribution remained unchanged, i.e., the fibrillae did not collapse into perinuclear aggregates as they did in cultured fibroblast. Also, no structures in addition to those seen in untreated retinas were brought out by the drug.

Optic fiber layer. At the inner edge of the retina the ends of the radial fibrillae in the Müller cells turned parallel to the vitreal surface, appearing in transverse sections as a system of obliquely and horizontally oriented segments (Fig. 14). In transverse sections no difference was obvious here between $\mathrm{R} 4$ and R5 labeling, but flat views revealed that the Müller fibers obscured an additional cell type which reacted only with R5 and not at all with R4. Figure 16 shows a whole mount stained with R5. Between the Müller end feet, large flat cells are labeled, extending multiple broad processes over the inner surface of the retina, the astrocytes of the optic fiber layer (Ramón y Cajal, 1911; Ogden, 1978; Büssow, 1980). These cells were also labeled with vimentin antisera (not shown).

The astroglia of the optic fiber layer was never labeled with R4, as shown in Figure 17, a horizontal section of the inner retinal surface double labeled with $\mathrm{R} 4$ and an antiserum to GFAP. With R4 (upper panel of Fig. 17) only the Müller end feet are visible, lining blood vessels and optic fiber bundles. No astrocytes are apparent, yet the GFAP labeling (lower panel) shows that there were plenty of astrocytes in the field. The mouse retina was, in fact, covered throughout with a loose network of astrocytes.

The GFAP antiserum seemed to label astrocytes throughout their extent, and it brought out particularly well their relationship to blood vessels. The antigen recognized by $\mathrm{R} 5$, however, like vimentin in these cells, was restricted to perinuclear regions and proximal large processes but was absent from the most distal parts of the cells. Double labelings with R5 and GFAP antiserum showed, in addition, that the two antigens were similarly localized in fibrillae but often differed in fine details of distribution even in perinuclear regions, indicating that they were probably not part of the same substructure.

Outer plexiform layer. At the level of the outer plexiform layer both R4 and R5 stained a tangle of thick, horizontally arborizing processes that resembled the cells labeled with the neurofilament antibody R3 in cross-sections (Fig. 14) and flat views; Figure 18 shows a horizontal section through the outer plexiform layer stained with R4. Camera lucida tracings of single elements revealed cells of a shape similar to the horizontal cell shown in Figure 12. Double labelings of R4 and R5 with R3 were not possible with indirect immunohistochemistry, since all three antibodies were of the IgM class. Nevertheless, double labelings with vimentin antiserum provided indirect evidence that the antigens coexisted in axonless horizontal cells, since each of the monoclonal antibodies co-labeled with the antiserum. Coexistence of the R4 and R5 antigen with

not equidistant. The fiber followed through the focal planes is indicated by arrows. Focal levels in the retina were determined by phase contrast microscopy or by labeling the whole mounts in addition with peanut agglutinine that has a selective affinity for the inner and outer segments and pedicles of cones (Blanks and Johnson, 1983). 


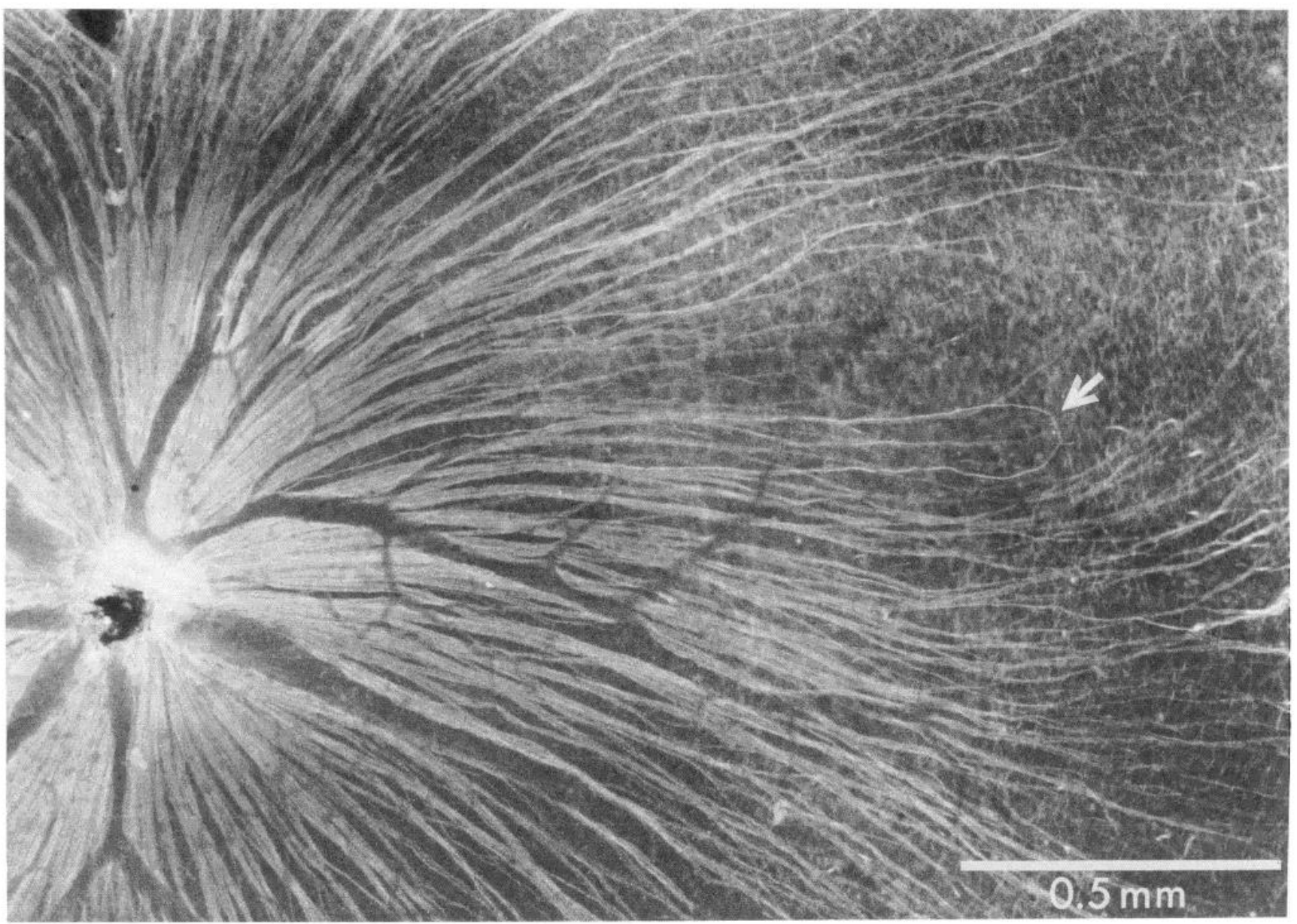

Figure 9. Low power view of a looping fiber.

neurofilaments in axonless horizontal cells makes these cells quite exceptional since no other neurons in the retina or brain were found to be R4- or R5-positive.

\section{Discussion}

We have described the immunological detection and light microscopical localization of fibrillar components in cells of the mouse retina, using monoclonal antibodies made against the isolated ganglion cell layer. Although we have not proven by ultrastructural analysis that the antigens recognized are associated with 10 -nm filament systems, their light microscopic appearance, reaction to colchicine, and, for $\mathrm{R} 3$, biochemical properties all make it likely that they are related to intermediate filaments.

Antibody R3 labeled a 185,000 - to 200,000 -dalton polypeptide that is most probably the large subunit of neurofilaments. Its labeling pattern in the retina was the same as we saw with RT 97, a monoclonal antibody against the high molecular weight neurofilament subunit (Anderton et al., 1982; Dräger, 1983). R3 appeared to label all structures in the retina that have been found to stain with neurofibrillar methods except for the cell body regions of large ganglion cells, which are known to stain with such methods in retinas of all species examined, including the mouse (Embden, 1901; Sala, 1904; Ramón y Cajal, 1911; Cattaneo, 1922; Gallego, 1964, 1982; Leicester and Stone, 1967; Honrubia and Elliott, 1968, 1969, 1970; Goldberg and Galin, 1973; Wässle et al., 1978, 1981; Vaney et al., 1981). The R3 antigen was not detectable above background levels in cell bodies, dendrites, and proximal axons of ganglion cells with the exception of an occasional cell that seemed to be labeled by accident. This discrepancy is most likely explained by the greater selectivity of the monoclonal antibody as compared to reduced silver methods. The Bodian neurofibrillar method has been shown to stain all three subunits of the neurofilament triplet (Gambetti et al., 1981), whereas R3 recognized mainly the heaviest subunit. With an antiserum to the intermediate molecular weight subunit of the neurofilament triplet we saw much more extensive labeling of ganglion cells than with R3, in a pattern reminiscent of neurofibrillar stains (Dräger et al., 1983). The assumption that the antigenic site on the 200,000-dalton neurofilament subunit recognized by $\mathrm{R} 3$ is not present in detectable amounts in all neurofilaments is in agreement with the observations of Shaw et al. (1981), who found all three neurofilament subunits to coexist in axons, but a few neurofilament-positive profiles, some of which they identified as dendrites of pyramidal cells, were lacking the heavy subunit. Unexplained remains the intracellular distribution of the R3 antigen in ganglion cells. Why is the antigen not detectable in the first several hundred micrometers of the axons, although it is synthesized in the cell body and transported down the axon at a slow rate (Hoffman and Lasek, 1975)?

In an attempt to bring out labeling of ganglion cell bodies, we applied colchicine to the retina and found two effects of the drug. First, several hours after drug application, the labeling was in general more intense, and the light microscopically visible fibrillae appeared thicker. This was true for the R3positive fibrillae as well as for the fibrillae labeled by antibodies R4 and R5. Second, in a slower time course, colchicine caused an intracellular expansion of the R3 antigen in ganglion cells, with optimal labeling of somata and dendrites about a day after drug application. The first effect may be the immunohistochem- 

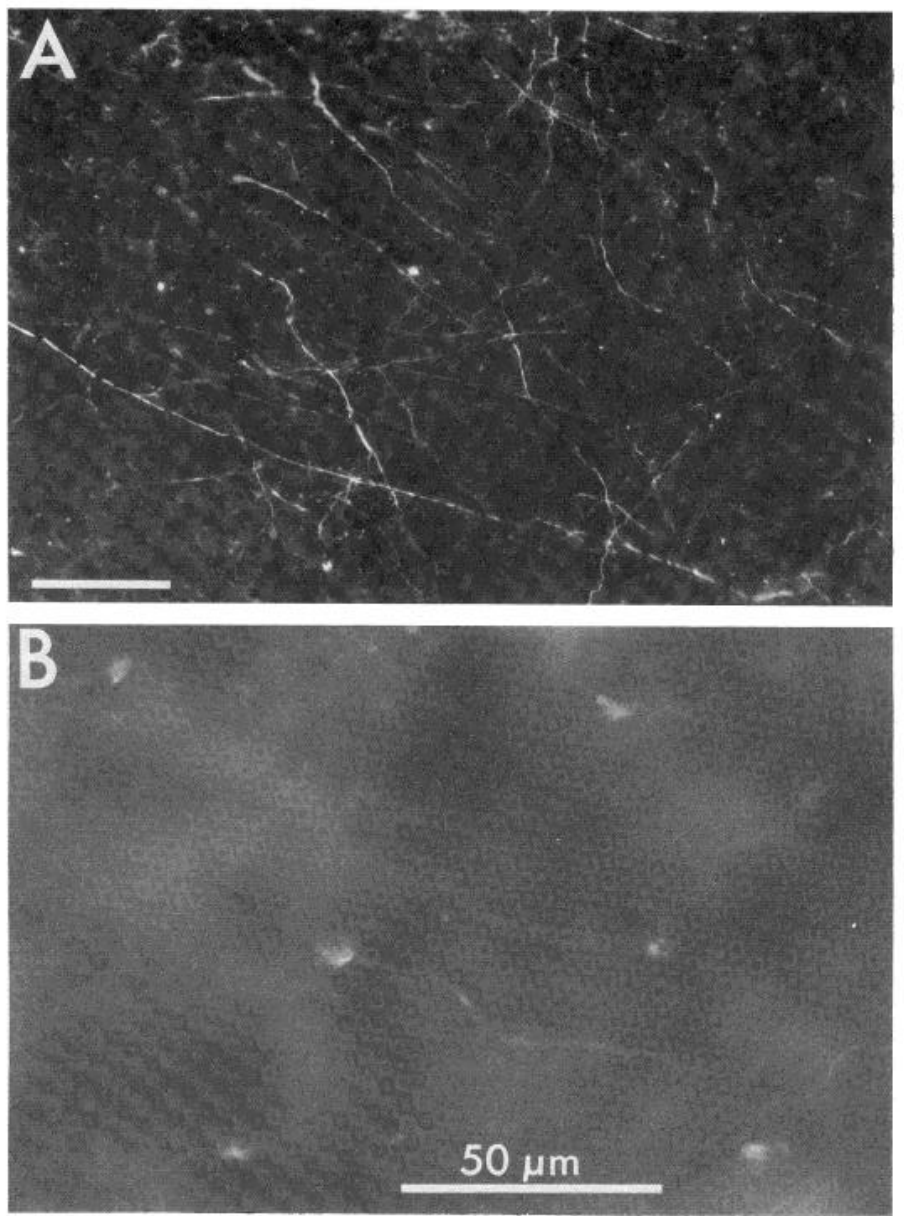

Figure 10. Two types of amacrine cells that appeared partially labeled by R3. A, Horizontal section through the inner plexiform layer showing thin, horizontally projecting processes (see also Fig. $7 F$ ). Single fibers could span a third or more of the extent of the retina. They may represent the dendrites of Perry's (Perry and Walker, 1980; Perry, 1981) wide field amacrine cells. $B$, Whole mount with focus on the inner row of cells in the inner nuclear layer, showing weakly labeled cell bodies that may correspond to the neurofilamentous type of amacrine cell described in the rabbit by Vaney et al. (1981).

ical correlate of the increase in neurofilaments seen at ultrastructural level after colchicine application (Wisniewski and Terry, 1967; Hansson and Sjöstrand, 1972). It was peculiar that the intracellular distribution of fibrillae in ganglion cells of drug-treated retinas was not substantially different from the few ganglion cells labeled without colchicine. Similarly the R4and R5-positive fibrillae in colchicine-treated retinas, as well as the fibrillae labeled with vimentin antisera, appeared coarser but otherwise normal in distribution; neither in neurons nor in glial cells did we see a perinuclear collapse of fibrillae, although the colchicine dosages used were large enough to cause eventual necrosis of the retina. The perinuclear collapse of intermediate filaments seen upon colchicine application to cultured cells is thought to be due to rapid disassembly of microtubules to which the filaments are linked (Peterson and Murray, 1966; Hynes and Destree, 1978). For the retina the deleterious effects of colchicine on microtubules appears to vary with cell type and species studied (Karisson et al., 1971; Davidson et al., 1983).

In the cat retina neurofibrillar stains have been used to study the mosaic of one functional class of ganglion cells, the $\alpha$ - or $\mathrm{Y}$-cells, which form the largest population of ganglion cells (Wässle et al., 1981). In the mouse retina the ganglion cells labeled with R3 after colchicine exposure were of the largest size, and they comprised a relatively high fraction of displaced ganglion cells, a population that from indirect evidence appears to include many cells homologous to $\alpha$-type ganglion cells of the cat (Cooper and Pettigrew, 1979; Dräger and Olsen, 1980). Whether the R3-labeled cells in the mouse do, in fact, correspond to one functional class remains to be tested. This question will be more easily addressed with neurofilament antibodies to lower molecular weight subunits, in order to avoid the use of colchicine.

R3 brought out some unexpected anatomical pecularities: ganglion cells with axonal arbors confined to the retina, previously called associational ganglion cells (Gallego and Cruz, 1965; Mariani, 1982), and fibers projecting to the retina from elsewhere, efferent fibers. Associational ganglion cells have been observed with neurofibrillar stains in retinas of dog and human. By no means do they represent one of the accepted cellular elements of the retina; at best, they are considered a rarity. Efferent fibers have been identified with reduced silver stains and other methods since the last century, yet, except for birds and some cold-blooded vertebrates, skepticism prevails as to their existence or at least to their physiological significance (Ramón y Cajal, 1894; Dogiel, 1895; Polyak, 1957; Cowan and Powell, 1963; Brooke et al., 1965; Brindley and Hamasaki, 1966; Ogden, 1966; Honrubia and Eliott, 1968, 1970; Witkovsky, 1971; Miles, 1972; Van Hasselt, 1972/73; Lin and Ingram, 1973; Goldberg and Galin, 1973; Noback and Mettler, 1973; Sandeman and Rosenthal, 1974; Marchiafava, 1976; Repérant and Gallego, 1976). In our material we found one or a few R3labeled efferents in most retinas. In view of the 70,000 afferent fibers (Dräger and Olsen, 1981), their number is minute, leaving the question open of whether they represent a very specialized function or merely an atavism. However, it is possible that we labeled only a fraction of these fibers. The efferent fiber shown in Figure 7, which terminated high in the inner plexiform layer, corresponds to the type common in birds and lower vertebrates (Cowan and Powell, 1963). About as often as this type we saw efferent fibers with more bizarre projection patterns. Some ended in the outer plexiform layer, others ended at the level of the photoreceptor outer processes (Fig. 8), and some projected beyond the peripheral (ciliary) edge of the retina. The looping fibers seen here (Figs. $7 E$ and 9 ) have been observed before by Goldberg and Galin (1973), who considered them also to be efferent fibers. The cell bodies of any of these fibers have yet to be located (Itaya, 1980; Bunt and Lund, 1981; Springer, 1982; Demski and Northcutt, 1983).

The antigens recognized by antibodies $\mathrm{R} 4$ and $\mathrm{R} 5$ were less restricted in tissue distribution than the R3 antigen, which was present only in neurons. They were found in a variety of nonneural tissues, as well as in cells of neuroectodermal origin. In all locations that we examined they were morphologically associated with vimentin, but not quite all vimentin-positive fibrillae were accompanied by them. (There was one exception to the co-localization with vimentin. In some preparations $\mathrm{R} 4$ labeled the nuclear stroma in a granular way, but this was variable, possibly related to fixation or extent of detergent treatment.) Since we do not know the molecular weight of the $\mathrm{R} 4$ and R5 antigens, it is not clear whether they relate to vimentin-associated proteins described by others (Granger and Lazarides, 1980; Granger et al., 1982; Wang et al., 1983). It is also possible, and more so for R5 than R4, that the antibodies are directed against or cross-react with an epitope on the vimentin molecule which is inaccessible in some locations.

Antibody R5 labeled in the retina the Müller glia, astrocytes in the optic fiber layer, and one type of neuron, the axonless horizontal cells. The labeling pattern was very similar to the retinal distribution of vimentin, except that the radial glia seemed to be slightly more pronounced in the inner retina with 


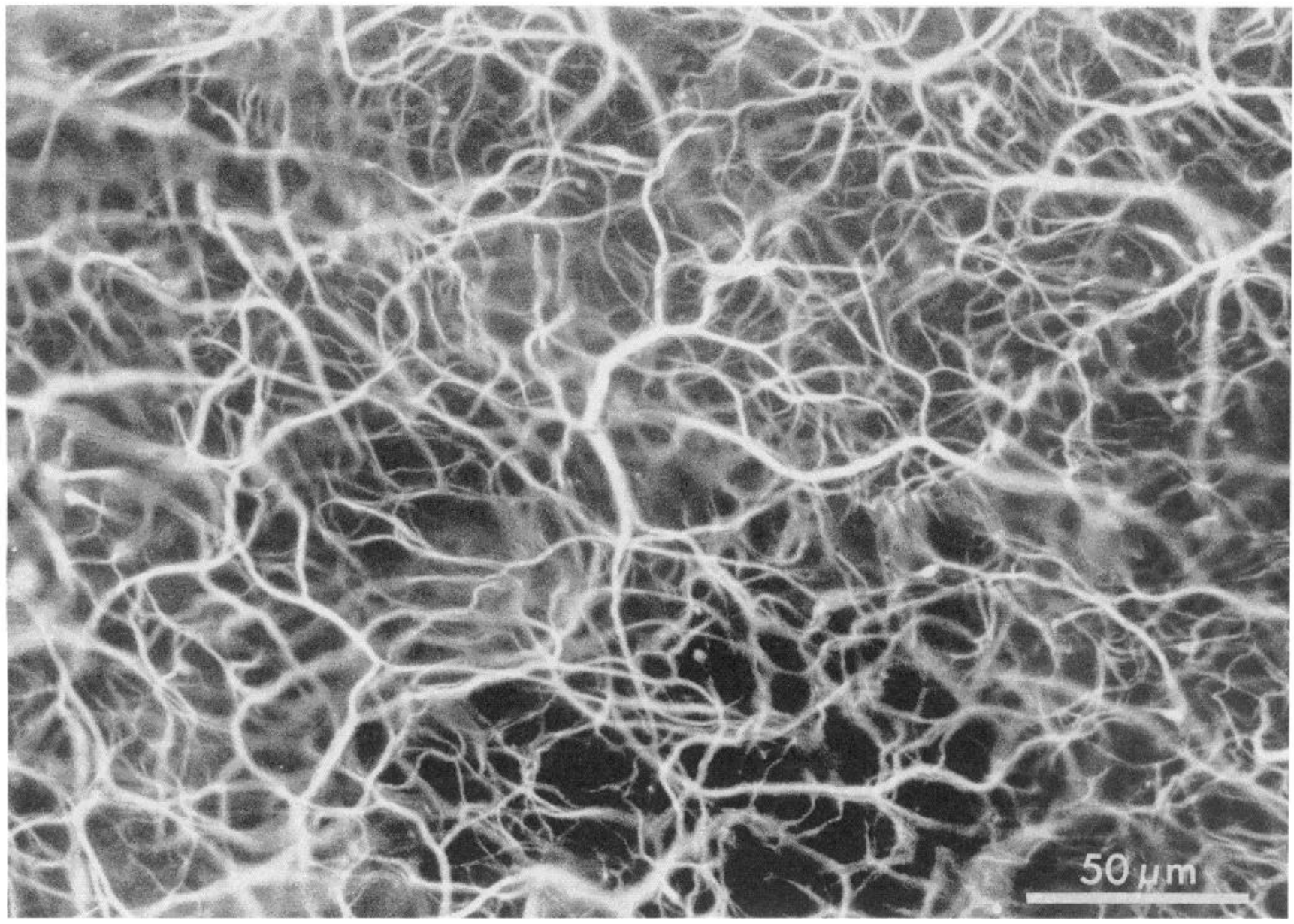

Figure 11. Whole mount labeled with R3. The focus is on the outer plexiform layer.

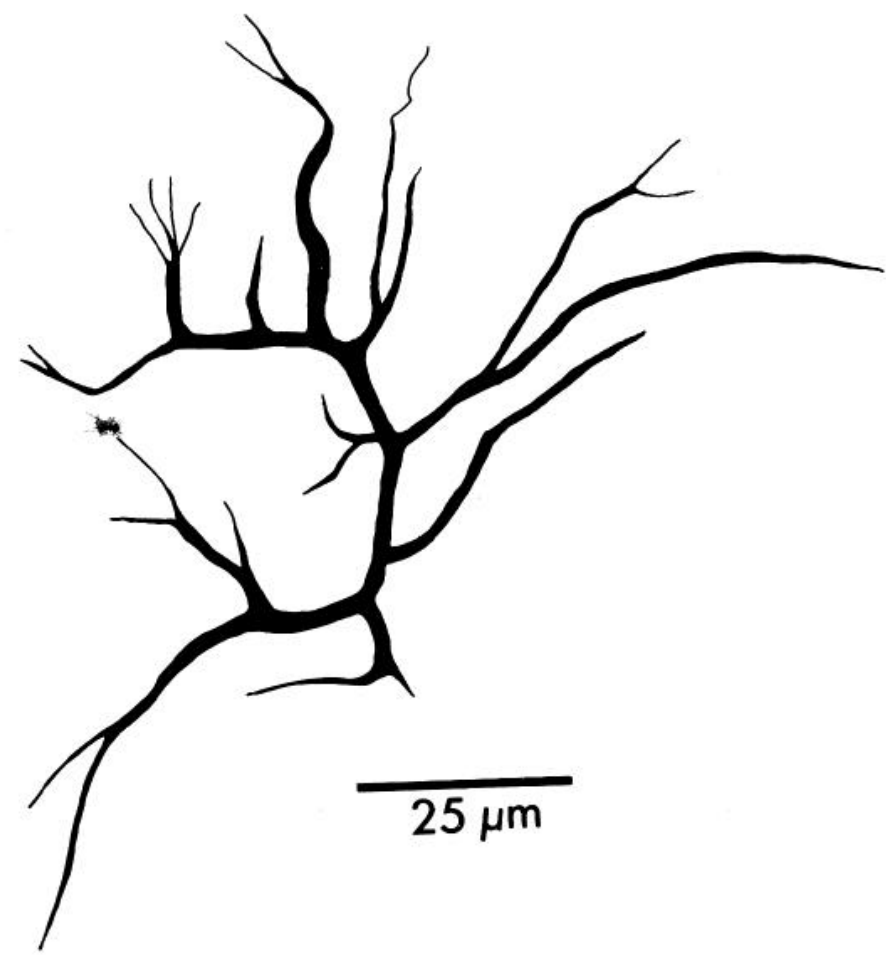

Figure 12. Camera lucida drawing of one of the elements labeled with R3 in the outer plexiform layer, an axonless horizontal cell.
R5 than with vimentin (Schnitzer et al., 1981; Dahl and Bignami, 1982). Like vimentin, the R5 antigen in the astroglia of the optic fiber layer was restricted to proximal parts of the cells (Dahl et al., 1981b). Antibody R4 labeled the radial Müller glia and the axonless horizontal cells but not the astroglia of the fiber layer. The retinal distribution of the $\mathrm{R} 4$ antigen resembled the $\mathrm{C} 1$ antigen of Sommer et al. (1981). Like R4, anti-C1 stains only the Müller cells but not the astroglia of the optic fiber layer. Such a selectivity is noteworthy, since Müller cells are considered a specialized form of astroglia (Polyak, 1957).

Only one type of neuron was labeled by R4 and R5 in the retina and probably in the entire central nervous system (CNS), the neurofilament-rich axonless horizontal cell. This peculiar neuron was also positive for vimentin, which is otherwise never expressed in mature neurons (Dräger, 1983; Shaw and Weber, 1983). Axonless horizontal cells, as well as horizontal cells in general, have several unusual characteristics, some of which were used in the past as arguments to question their neural identity (Sala, 1904; Villegas and Villegas, 1963; Svaetichin et al., 1965; see Rodieck, 1973, and Wässle et al., 1978, for discussions of the literature). In a study of retinal glia with modifications of the del Rio-Hortega silver carbonate stain for astroglia, Lessell and Kuwabara (1963) found the axonless horizontal cells to be stained, which they attributed to insufficient selectivity of these methods. Since we confirmed their observations with antibodies to vimentin and related molecules, the silver carbonate methods now appear to be vindicated. It would be interesting to try to adapt these methods to gel-separated proteins to test whether they have an affinity to vimentin or 

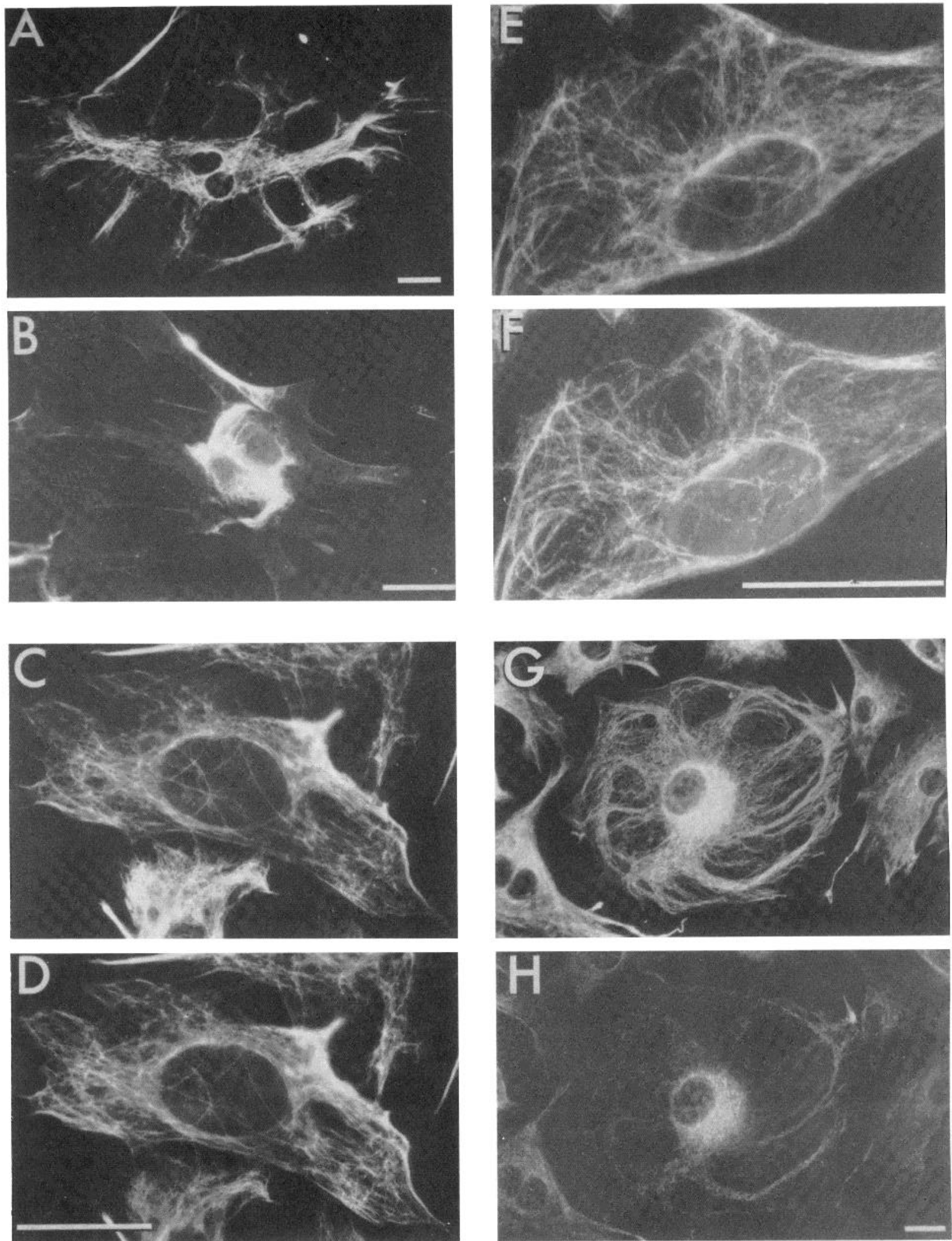

Figure 13. $A$ and B, Fibroblasts extracted from newborn rat lungs. Cells in $B$ were exposed to $20 \mu \mathrm{g}$ of colchicine for $15 \mathrm{hr}$. Both preparations were labeled with R5. $C$ and $D, 3$ T3 cells double labeled with vimentin antiserum $(c)$ and R5 $(D)$. Note the identical labeling. $E$ and $F, 3$ T3 cells double labeled with vimentin antiserum $(E)$ and $\mathrm{R} 4(F)$. Note that the R4 antigen along the vimentin fibrillae appears fragmented. $G$ and $H$, $\epsilon^{\prime}$ c. 1 cells double labeled with vimentin antiserum $(G)$ and R5 $(H)$. All scales indicate $30 \mu \mathrm{m}$. 

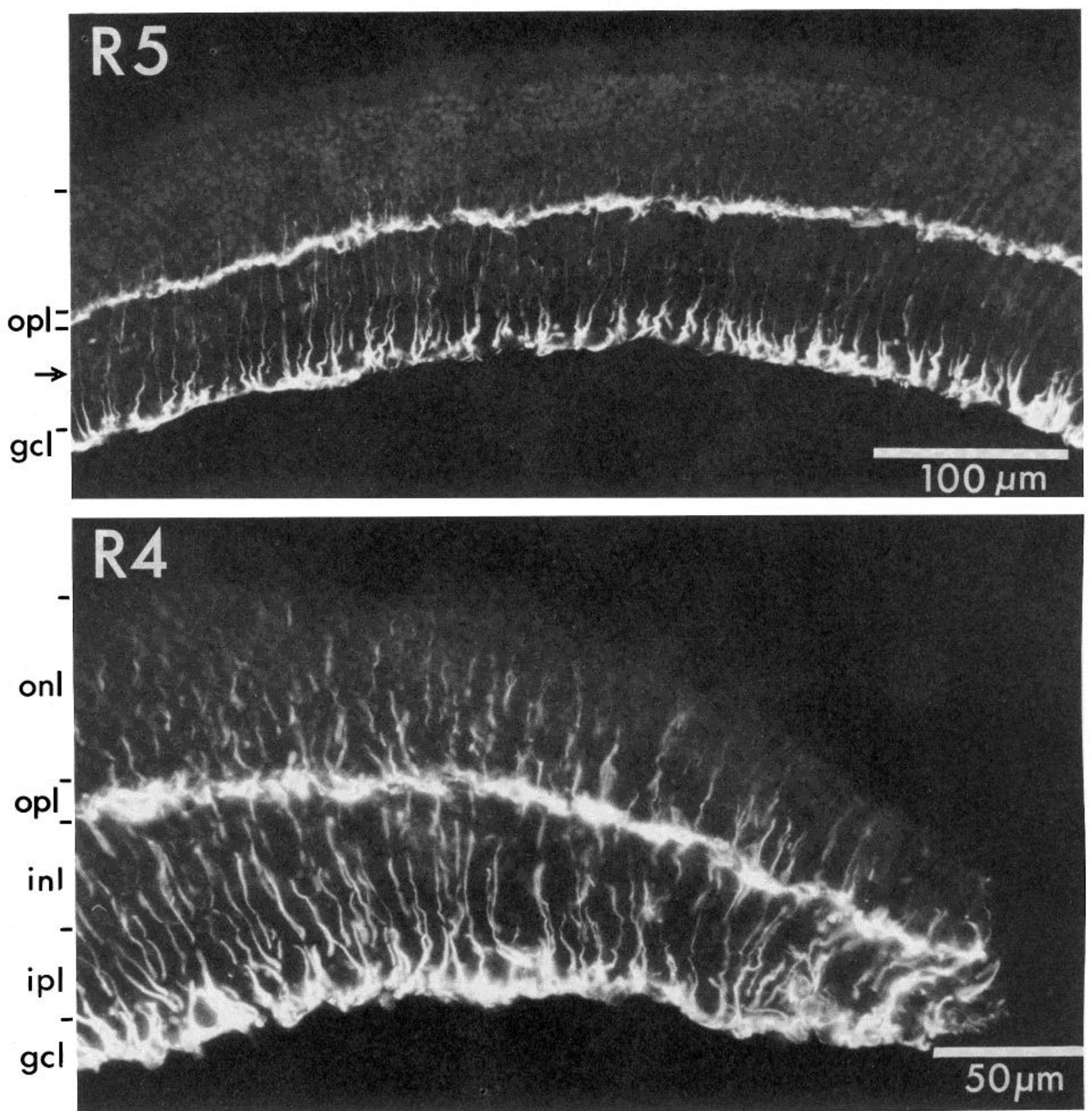

Figure 14. Transverse sections of retina labeled with R5 (upper panel) and R4 (lower panel). With both antibodies the labeling of the radial Müller fibers was more extensive close to the ciliary edge of the retina (lower panel). There were no obvious differences in the labeling of transverse sections between the two antibodies. Retinal laminae are indicated as in Figure 2. The location of the cell bodies of the Müller glia is pointed out by the arrow in the upper panel. 


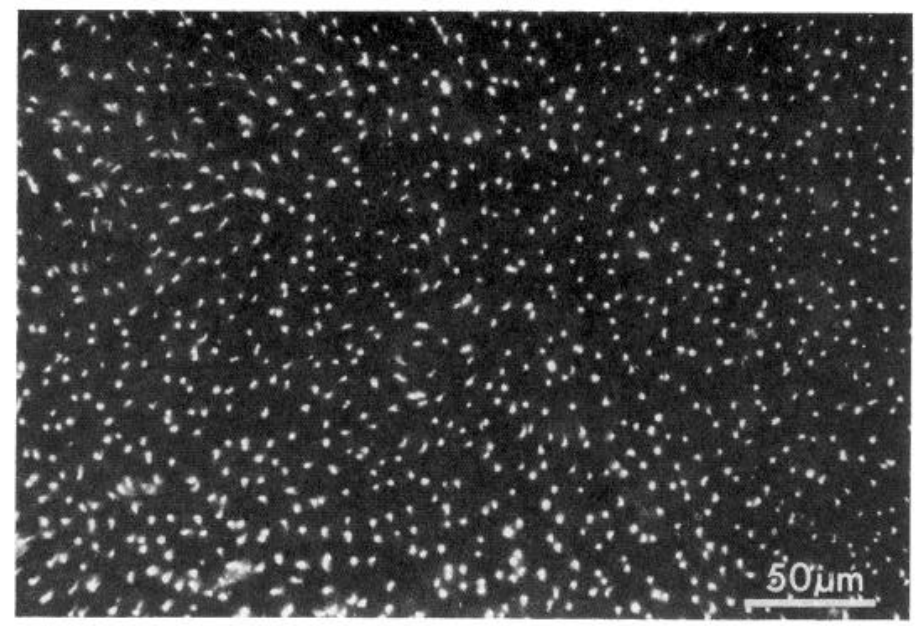

Figure 15. Horizontal section through outer part of inner plexiform layer labeled with R4 and R5 together to increase intensity, showing mosaic of Müller cells. Further inward toward the ganglion cell layer each Müller process divided into two or more end feet. Histograms of distances between nearest neighbors were made from photomicrographs such as this.

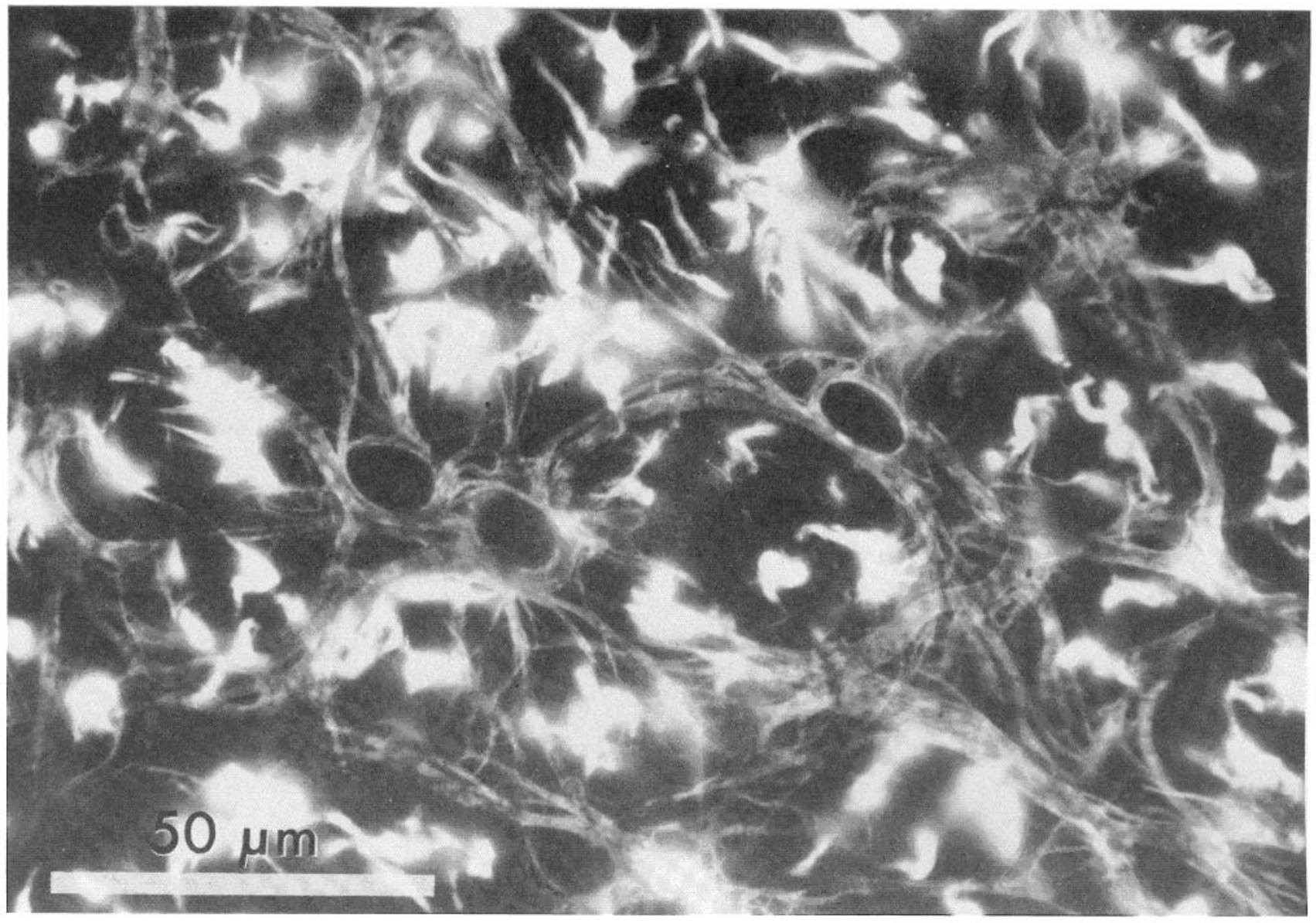

Figure 16. Whole mount of a $\mathrm{C} 3 \mathrm{H} / \mathrm{HeJ} r d / r d$ retina reacted with $\mathrm{R} 5$. Note the astrocytes located at the vitreal margin of the retina between the Müller end feet. The same cells were visible in retinas of C57BL/6J mice (not shown), but in degenerate $(r d / r d)$ retinas they appeared more prominent, which presumably reflected the known fibrous reaction of astrocytes to injury (Dahl et al., 1981b). 


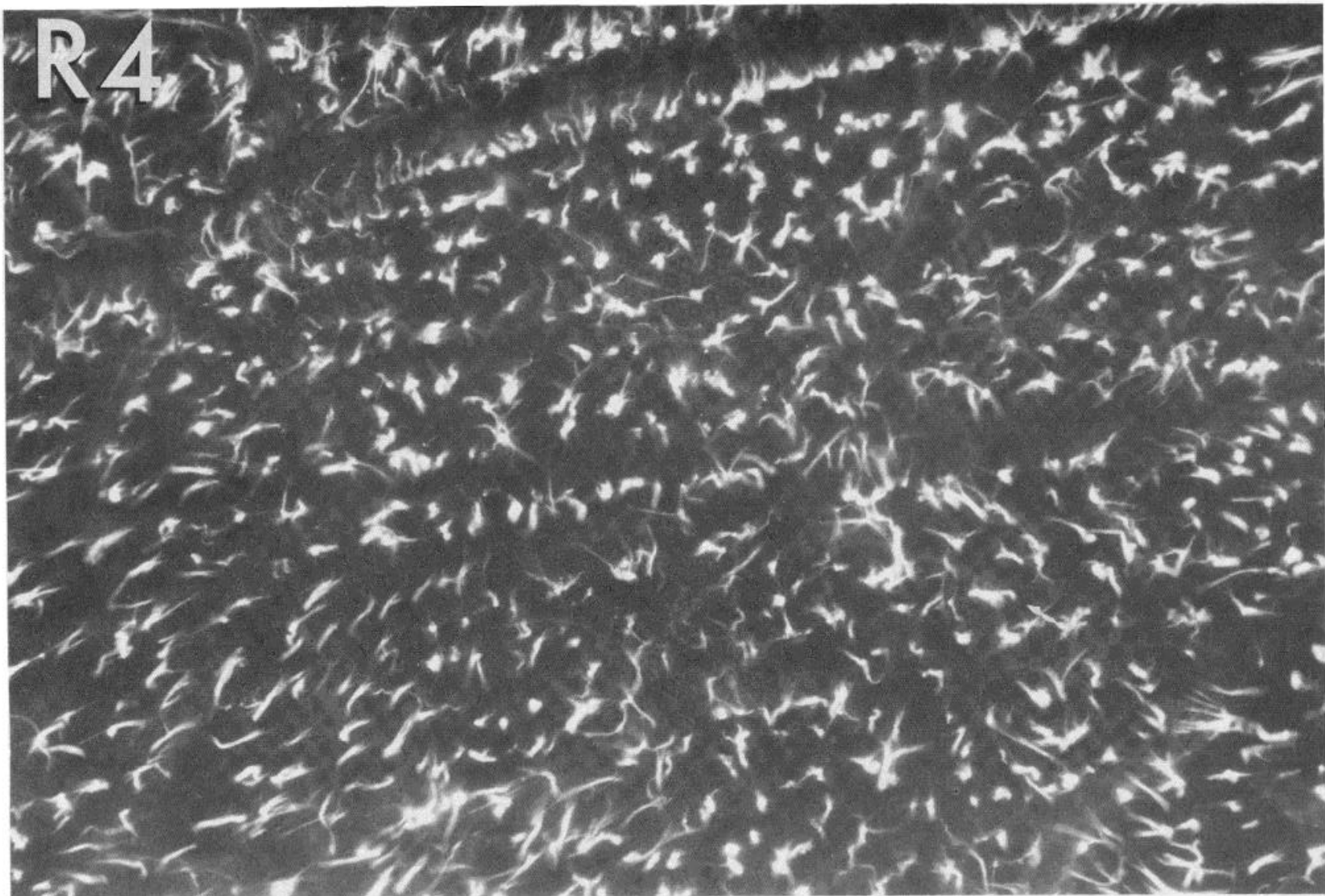

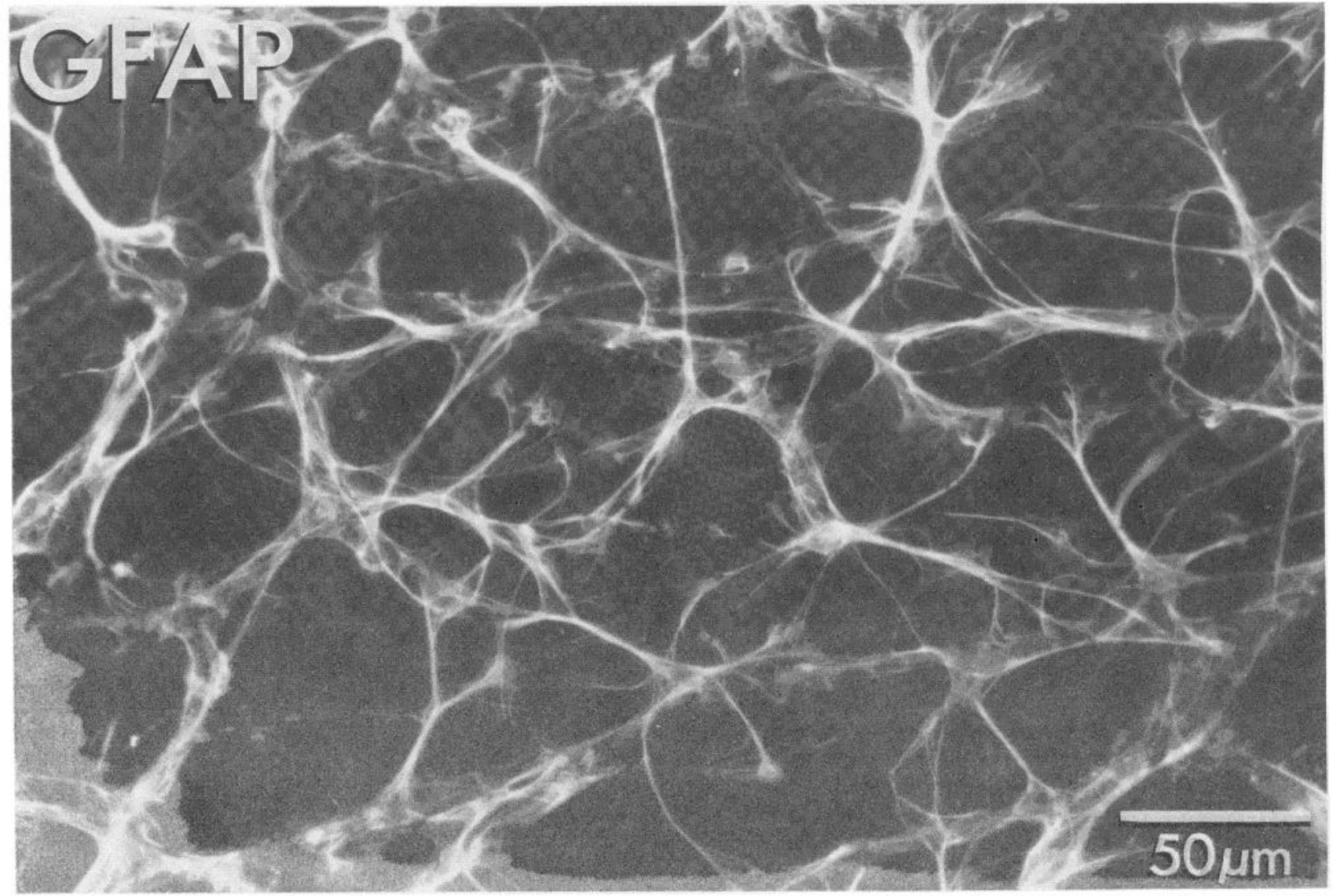

Figure 17. Flat section of the ganglion cell layer of a C57BL/6J mouse double-labeled with R4 (upper panel, FITC) and GFAP antiserum (lower panel, RITC). Note the lining of blood vessels by the Müller end feet and the extension of bulbous processes by the astrocytes to the same blood vessels. 


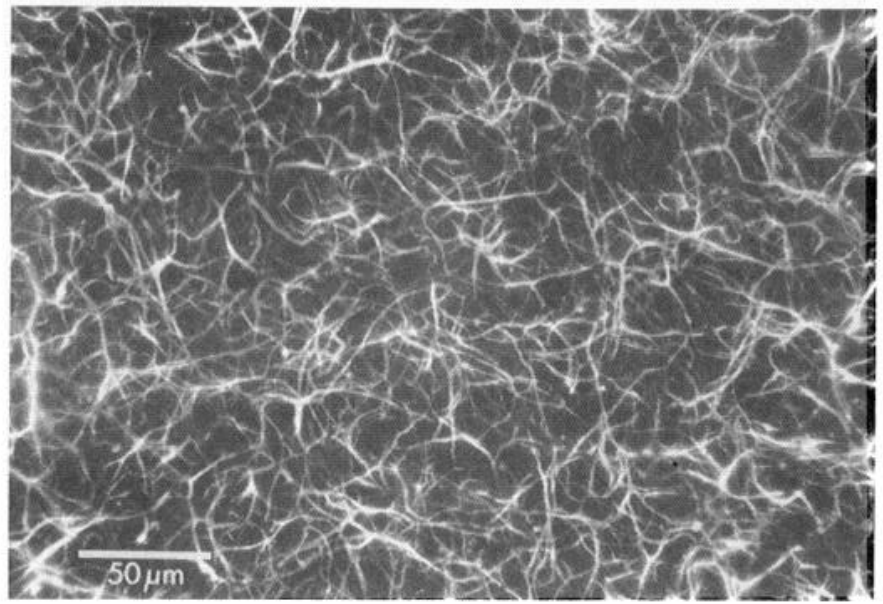

Figure 18. Flat (horizontal) section through the outer plexiform layer, showing axonless horizontal cells labeled with R4.

one of the related factors, in analogy to the finding of Gambetti et al. (1981) that the Bodian stain can be used to detect neurofilaments on gels. It seems to be more than a coincidence that a filament system, otherwise found exclusively in glia in the adult CNS, turns up in a neuron that had been suspected on totally different grounds to be glial or glia-like. This observation, as well as the heterogeneity and cell type specificity of intermediate filaments, seems to point to a more specific function fo these filament systems beyond a simple structural role.

\section{References}

Anderton, B. H., D. Breinburg, M. J. Downes, P. J. Green, B. E. Tomlinson, J. Ulrich, J. N. Wood, and J. Kahn (1982) Monoclonal antibodies show that neurofibrillary tangles and neurofilaments share antigenic determinants. Nature 298: 84-86.

Barnstable, C. J. (1980) Monoclonal antibodies which recognize different cell types in the rat retina. Nature 286: $231-235$.

Barnstable, C. J. (1982) Immunological studies of the retina. In Neuroimmunology, J. Brockes, ed., pp. 183-214, Plenum Press, New York.

Beale, R., and N. N. Osborne (1982) Localization of the Thy-1 antigen to the surface of rat retinal ganglion cells. Neurochem. Int. 4: 587595.

Bignami, A., and D. Dahl (1979) The radial glia of Müller in the rat retina and their response to injury. An immunofluorescence study with antibodies to the glial fibrillary acidic (GFA) protein. Exp. Eye Res. 28: 63-69.

Blanks, J. C., and L. V. Johnson (1983) Selective lectin binding of the developing mouse retina. J. Comp. Neurol. 221: 31-41.

Bloomfield, S. A., and R. F. Miller (1982) A physiological and morphological study of the horizontal cell types of the rabbit retina. J. Comp. Neurol. 208: 288-303.

Boycott, B. B., L. Peichl, and H. Wässle (1978) Morphological types of horizontal cells in the retina of the domestic cat. Proc. R. Soc. Lond. Biol. 203: 229-245.

Brindley, G. S., and D. I. Hamasaki (1966) Histological evidence against the view that the cat's optic nerve contains centrifugal fibers. J. Physiol. (Lond.) 184: 444-449.

Bromberg, J. S., and M. Schachner (1978) Localization of nervous system antigens in retina by immunohistology. Invest. Ophthalmol. Vis. Sci. 17: 920-924.

Brooke, R. N. L., J. de C. Downer, and T. P. S. Powell (1965) Centrifugal fibres to the retina in the monkey and cat. Nature 207: 13651367.

Bulloch, K., W. B. Stallcup, and M. Cohn (1978) A new method for the establishment of neuronal cell lines from the mouse brain. Life Sci. 22: 495-504.

Bunt, S. M., and R. D. Lund (1981) Development of a transient retinoretinal pathway in hooded and albino rats. Brain Res. 211: 399-404. Büssow, H. (1980) The astrocytes in the retina and optic nerve head of mammals: A special glia for the ganglion cell axons. Cell Tissue Res. 206: $367-378$.

Cattaneo, D. (1922) La struttura della retina dei vertebrati. Ann. Ottamol. 50: 349-390.

Cooper, M. L., and J. D. Pettigrew (1979) The retinothalamic pathway in Siamese cats. J. Comp. Neurol. 187: 313-348.

Cowan, W. M. and T. P. S. Powell (1963) Centrifugal fibres in the avian visual system. Proc. R. Soc. Lond. Biol. 158: 232-252.

Dacheux, R. F., and E. Raviola (1982) Horizontal cells in the retina of the rabbit. J. Neurosci. 2: 1486-1493.

Dahl, D., and A. Bignami (1982) Immunohistological localization of desmin, the muscle-type $100 \AA$ filament protein, in rat astrocytes and Müller glia. J. Histochem. Cytochem. 30: 207-213.

Dahl, D., A. Bignami, N. T. Bich, and N. H. Chi (1981a) Immunohistochemical localization of the $150 \mathrm{~K}$ neurofilament protein in the rat and the rabbit. J. Comp. Neurol. 195: 659-666.

Dahl, D., A. Bignami, K. Weber, and M. Osborn (1981b) Filament proteins in rat optic nerves undergoing Wallerian degeneration: Localization of vimentin, the fibroblastic $10-\AA$ filament protein, in normal and reactive astrocytes. Exp. Neurol. 73: 496-506.

Davidson, C., W. R. Green, and V. G. Wong (1983) Retinal atrophy induced by intravitreous colchicine. Invest. Ophthalmol. Vis. Sci. 24: 301-311.

Demski, L. S., and R. G. Northcutt (1983) The terminal nerve: A new chemisensory system in vertebrates? Science $220: 435-437$.

Dixon, R. G., and L. F. Eng (1981) Glial fibrillary acidic protein in the retina of the developing albino rat: An immunoperoxidase study of paraffin-embedded tissue. J. Comp. Neurol. 195: 305-321.

Dogiel, A. S. (1895) Die Retina der Vögel. Arch. Mikrosk. Anat. Entwicklungs. Mech. 44: 622-648.

Dräger, U. C. (1983) Coexistence of neurofilaments and vimentin in a neuron of the adult mouse retina. Nature 303: 169-172.

Dräger, U. C., and D. L. Edwards (1983) Antibodies to intermediate filaments reveal abnormalities in retinas of mice with photoreceptor degeneration. Invest. Ophthalmol. Vis. Sci. Suppl. 24: 115.

Dräger, U. C., and J. F. Olsen (1980) Origins of crossed and uncrossed retinal projections in pigmented and albino mice. J. Comp. Neurol. 191: $383-412$.

Dräger, U. C., and J. F. Olsen (1981) Ganglion cell distribution in the retina of the mouse. Invest. Ophthalmol. Vis. Sci. 20: 285-293.

Dräger, U. C., D. L. Edwards and J. Kleinschmidt (1983) Neurofilaments contain $\alpha$-melanocyte-stimulating hormone ( $\alpha$-MSH)-like immunoreactivity. Proc. Natl. Acad. Sci. U. S. A. 80: 6408-6412.

Embden, G. (1901) Primitivfibrillenverlauf in der Netzhaut. Arch. Mikrosk. Anat. 57: 570-583.

Fisher, S. K., and B. B. Boycott (1974) Synaptic connexions made by horizontal cells within the outer plexiform layer of the retina of the cat and the rabbit. Proc. R. Soc. Lond. Biol. 186: 317-331.

Franke, W. W., E. Schmid, M. Osborn, and K. Weber (1978) Different intermediate-sized filaments distinguished by immunofluorescence microscopy. Proc. Natl. Acad. Sci. U. S. A. 75: 5034-5038.

Gallego, A. (1964) Description d'une nouvelle couche cellulaire dans la rétine des mammiferes et son rôle fonctionnel possible. Bull. Assoc. Anat. Paris 49: 624-631.

Gallego, A. (1982) Organization of the outer plexiform layer of the tetrapoda retina: Horizontal cells of mammalian and avian retina. In The Structure of the Eye, J. G. Hollyfield, ed., pp. 151-164, Elsevier-North Holland, Amsterdam.

Gallego, A., and J. Cruz (1965) Mammalian retina: Associational nerve cells in ganglion cell layer. Science 150: 1313-1314

Gambetti, P., L. Autilio-Gambetti, and S. C. Papasozomenos (1981) Bodian's silver method stains neurofilament polypeptides. Science 213: $1521-1522$.

Goldberg, S., and M. A. Galin (1973) Response of retinal ganglion cell axons to lesions in the adult mouse retina. Invest. Ophthalmol. 12: 383-385.

Granger, B. L., and E. Lazarides (1980) Synemin: A new high molecular weight protein associated with desmin and vimentin filaments. Cell 22: $727-738$.

Granger, B. L., E. A. Repasky, and E. Lazarides (1982) Synemin and vimentin are components of intermediate filaments in avian erythrocytes. J. Cell Biol. 92: 299-312.

Gray, E. G., and R. W. Guillery (1961) The basis for silver staining of synapses of the mammalian spinal cord: A light and electron microscope study. J. Physiol. (Lond.) 157: 581- 588 . 
Guillery, R. W. (1970) Light and electron-microscopical studies of normal and degenerating axons. In Contemporary Kesearch Methods in Neuroanatomy, W. J. H. Nauta and S. O. E. Ebbesson, eds., pp. 77-105, Springer-Verlag, Heidelberg.

Hanker, J. S., P. E. Yates, C. B. Metz, and A. Rustioni (1977) A new specific sensitive and non-carcinogenic reagent for the demonstration of horseradish peroxidase. Histochem. J. 9: 789-792.

Hansson, H.-A., and J. Sjöstrand (1972) Ultrastructural changes in duced in the rat retina by treatment with colchicine. Doc. Ophthalmol. 31: 2963 .

Hoffman, P., and R. J. Lasek (1975) The slow component of axonal transport. Identification of major structural polypeptides of the axon and their generality among mammalian neurons. J. Cell Biol. 66 . $351-366$.

Honrubia, F. M., and J. H. Elliott (1968) Efferent innervation of the retina. I. Morphologic study of the human retina. Arch. Ophthalmol. 80: $98-103$.

Honrubia, R. M., and J. H. Elliott (1969) Horizontal cell of the mammal retina. Arch. Ophthalmol. 82: 98-104.

Honrubia, F. M., and J. H. Elliott (1970) Efferent innervation of the retina. II. Morphologic study of the monkey retina. Invest. Ophthalmol. 9: 971-976.

Hynes, R. O., and A. T. Destree (1978) $10 \mathrm{~nm}$ filaments in normal and transformed cells. Cell 13: 151-163.

Itaya, S. K. (1980) Retinal efferents from the pretectal area in the rat. Brain Res. 201: 436-441.

Johnson, G. D., and G. M. de C. Nogueira Aranjo (1981) A simple method of reducing the fading of immunofluorescence during microscopy. J. Immunol. Methods 43: 349-50.

Karlsson, J.-O., H.-A. Hansson, and J. Sjöstrand (1971) Effect of colchicine on axonal transport and morphology of retinal ganglion cells. Z. Zellforsch. 115: 265-283.

Kolb, H. (1977) The organization of the outer plexiform layer in the retina of the cat: Electron microscopic observations. J. Neurocytol. 6: 131-153.

Laemmli, U. K. (1970) Cleavage of structural proteins during the assembly of the head of bacteriophage T4. Nature 227: 680-685.

Lazarides, E. (1980) Intermediate filaments as mechanical integrators of cellular space. Nature 283: 249-256.

Lazarides, E. (1981) Intermediate filaments-chemical heterogeneity in differentiation. Cell 23: 649-650.

Leicester, J., and J. Stone (1967) Ganglion, amacrine and horizontal cells of the cat's retina. Vision Res. 7: 695-705.

Lessell, S., and T. Kuwabara (1963) Retinal neuroglia. Arch. Ophthalmol. 70: 671-678.

Liem, R. K. H., S-H. Yen, G. D. Salomon, and M. L. Shelanski (1978) Intermediate filaments in nervous tissues. J. Cell Biol. 79: 637-645.

Lin, H., and W. R. Ingram (1973) Axonal degeneration in the peripheral optic pathway of the cat. Exp. Neurol. 39: 234-248.

Marchiafava, P. O. (1976) Centrifugal actions on amacrine and ganglion cells in the retina of the turtle. J. Physiol. (Lond.) 255: 137-155.

Mariani, A. P. (1982) Association amacrine cells could mediate directional selectivity in pigeon retina. Nature 298: 654-655.

Miles, F. A. (1972) Centrifugal control of the avian retina I-IV. Brain Res. 48: 65-145.

Noback, C. R., and F. Mettler (1973) Centrifugal fibers to the retina in the rhesus monkey. Brain Behav. Evol. 7: 382-399.

Ogden, T. E. (1966) On the function of efferent retinal fibres. In Structure and Function of Inhibitory Neuronal Mechanisms, C. Von Euler, S. Skoglund, and U. Söderberg, eds., Wenner-Gren International Symposium Series, Vol. 10, pp. 89-111, Pergamon Press, Oxford.

Ogden, T. E. (1978) Nerve fiber layer astrocytes of the primate retina: Morphology, distribution, and density. Invest. Ophthalmol. Vis. Sci. 17: 499-510.

Perry, V. H. (1981) Evidence for an amacrine cell system in the ganglion cell layer of the rat retina. Neuroscience 6: 931-944.

Perry, V. H., and M. Walker (1980) Amacrine cells, displaced amacrine cells and interplexiform cells in the retina of the rat. Proc. R. Soc. Lond. Biol. 208: 415-431.

Peters, A., S. Palay, and H. deF. Webster (1976) The Fine Structure of the Nervous System: The Neurons and Supporling Cells, W. B. Saunders Co., Philadelphia.

Peterson, E., and M. Murray (1966) Serial observations in tissue cultures on neurotoxic effects of colchicine. Anat. Rec. 154: 401.
Polyak, S. L. (1957) The Vertebrate Visual System, University of Chicago Press, Chicago.

Potter, H. D. (1971) The distribution of neurofibrils coextensive with microtubules and neurofilaments in dendrites and axons of the tectum, cerebellum, and pallium of the frog. J. Comp. Neurol. 143 : 385-410.

Pruss, R. M., R. Mirsky, M. C. Raff, R. Thorpe, A. J. Dowding, and B. $\mathrm{H}$. Anderton (1981) All classes of intermediate filaments share a common antigenic determinant defined by a monoclonal antibody. Cell 27: 419-428.

Ramón y Cajal, S. (1894) Die Retina der Wirbelthiere, Bergmann, Wiesbaden.

Ramón y Cajal, S. (1911) Histologie du Système Nerveux de l'Homme et des Vertébrés, A. Maloine, Paris. (Reprinted 1952, Consejo Superior de Investigaciones Cientificas, Instituto Ramón y Cajal, Madrid.)

Repérant, J., and A. Gallego (1976) Fibres centrifuges dans la rétine humaine. Arch. Anat. Microsc. Morphol. Exp. 65: 103-120.

Rodieck, R. W. (1973) The Vertebrate Retina, W. H. Freeman and Co., San Francisco.

Sala, G. (1904) Beitrag zum Studium der feineren Struktur der Netzhaut. Anat. Anz. 25: 246-249.

Sandeman, D. C., and N. P. Rosenthal (1974) Efferent axons in the fish optic nerve and their effect on the retinal ganglion cells. Brain Res. 68: 41-54.

Schachner, M., C. Smith, and G. Schoonmaker (1978) Immunological distinction between neurofilament and glial fibrillary acidic proteins by mouse antisera and their immunohistological characterization. Dev. Neurosci. 1: 1-14.

Schnitzer, J., W. W. Franke, and M. Schachner (1981) Immunocytochemical demonstration of vimentin in astrocytes and ependymal cells of developing and adult mouse nervous system. J. Cell Biol. 90: 435-447.

Sharp, G. A., G. Shaw, and K. Weber (1982) Immunoelectronmicroscopical localization of the three neurofilament triplet proteins along neurofilaments of cultured dorsal root ganglion neurons. Exp. Cell Res. 137: 403-413.

Shaw, G., and K. Weber (1982) Differential expression of neurofilament triplet proteins in brain development. Nature 298: 277-279.

Shaw, G., and K. Weber (1983) The structure and development of the rat retina: An immunofluoresence microscopical study using antibodies specific for intermediate filament proteins. Eur. J. Cell Biol. 30: $219-232$.

Shaw, G., M. Osborn, and K. Weber (1981) An immunofluorescence microscopical study of the neurofilament triplet proteins, vimentin and glial fibrillary acidic protein within the adult rat brain. Eur. J. Cell. Biol. 26: 68-82.

Sidman, R. L., and M. C. Green (1965) Retinal degeneration in the mouse. Location of the $r d$ locus in linkage group XVII. J. Hered. 56 . $23-29$.

Sommer, I., C. Lagenaur, and M. Schachner (1981) Recognition of Bergmann glial and ependymal cells in the mouse nervous system by monoclonal antibody. J. Cell Biol. 90: 448-458.

Springer, A. (1982) Retinopetal cells in the goldfish olfactory bulb. Invest. Ophthalmol. Vis. Sci. Suppl. 22: 246.

Svactichin, G., K. Negishi, R. Fatehchand, B. D. Drujan, and A. Selvin de Testa (1965) Nervous function based on interactions between neuronal and non-neuronal elements. Prog. Brain Res. 15: 243-266.

Towbin, H., T. Staehelin, and J. Gordon (1979) Electrophoretic transfer of proteins from polyacrylamide gels to nitrocellulose sheets: Procedure and some applications. Proc. Natl. Acad. Sci. U. S. A. 76: $4350-4354$

Vaney, D.I., L. Peichl, and B. B. Boycott (1981) Matching populations of amacrine cells in the inner nuclear and ganglion cell layers of the rabbit retina. J. Comp. Neurol. 199: 373-391.

Van Hasselt, P. (1972/73) The centrifugal control of retinal function. Ophthalmol. Res. 4: 298-320.

Villegas, G. M., and R. Villegas (1963) Neuron-glia relationship in the bipolar cell layer of the fish retina. J. Ultrastruct. Res. 8: 89-106.

Wang, E., J. G. Cairncross, W. K. A. Yung, E. A. Garber, and R. Liem (1983) An intermediate filament-associated protein, p50, recognized by monoclonal antibodies. J. Cell Biol. 97: 1507-1514.

Wässle, H., L. Peichl, and B. B. Boycott (1978) Topography of horizontal cells in the retina of the domestic cat. Proc. R. Soc. Lond Biol. 203: 269-291.

Wassle, H., L. Peichl, and B. B. Boycott (1981) Morphology and 
topography of on- and off-alpha cells in the cat retina. Proc. R. Soc. Lond. Biol. 212: 157-175.

Willard, M., and C. Simon (1981) Antibody decoration of neurofilaments. J. Cell Biol. 89: 198-205.

Wisniewski, H., and R. D. Terry (1967) Experimental colchicine encephalopathy. I. Induction of neurofibrillary degeneration. Lab. In- vest. $17: 577-587$

Witkovsky, P. (1971) Synapses made by myelinated fibers running to teleost and elasmobranch retinas. J. Comp. Neurol. 142: 205-222.

Yen, S-H., and K. L. Fields (1981) Antibodies to neurofilament, glial filament, and fibroblast intermediate filament proteins bind to different cell types of the nervous system. J. Cell Biol. 88: 115-126. 